NBER WORKING PAPER SERIES

\title{
THE EFFECT OF PUBLIC FUNDING ON RESEARCH OUTPUT: THE NEW ZEALAND MARSDEN FUND
}

\author{
Jason Gush \\ Adam B. Jaffe \\ Victoria Larsen \\ Athene Laws \\ Working Paper 21652 \\ http://www.nber.org/papers/w21652 \\ NATIONAL BUREAU OF ECONOMIC RESEARCH \\ 1050 Massachusetts Avenue \\ Cambridge, MA 02138 \\ October 2015
}

This project grew out of a suggestion made by Dean Peterson, formerly of the Royal Society of New Zealand. We are grateful to Ryan Burnell for compiling the publications information and to Dave Maré and Shaun Hendy for advice. Useful comments were provided by Ariel Dora Stern, Bronwyn Hall and seminar participants at University of Melbourne, University of Waikato, the New Zealand Economics Association, NBER Summer Institute and Otago University. Financial support from the Motu Research and Education Foundation, Queensland University of Technology and the Ministry of Business Innovation and Employment is gratefully acknowledged. All errors and opinions belong solely to the authors. The views expressed herein are those of the authors and do not necessarily reflect the views of the National Bureau of Economic Research.

At least one co-author has disclosed a financial relationship of potential relevance for this research. Further information is available online at http://www.nber.org/papers/w21652.ack

NBER working papers are circulated for discussion and comment purposes. They have not been peerreviewed or been subject to the review by the NBER Board of Directors that accompanies official NBER publications.

(C) 2015 by Jason Gush, Adam B. Jaffe, Victoria Larsen, and Athene Laws. All rights reserved. Short sections of text, not to exceed two paragraphs, may be quoted without explicit permission provided that full credit, including $(\odot)$ notice, is given to the source. 
The Effect of Public Funding on Research Output: the New Zealand Marsden Fund

Jason Gush, Adam B. Jaffe, Victoria Larsen, and Athene Laws

NBER Working Paper No. 21652

October 2015

JEL No. O31,O34,O38

\begin{abstract}
$\underline{\text { ABSTRACT }}$
We estimate the impact of participating in the NZ Marsden Fund on research output trajectories, by comparing the subsequent performance of funded researchers to those who submitted proposals but were not funded. We control for selection bias using the evaluations of the proposals generated by the grant selection process. We carry out the analysis in two data frames. First we consider the researcher teams behind 1263 second-round proposals submitted 2003-2008, and look at the post-proposal publication and citation performance of the team as a whole, as a function of pre-proposal performance, the ranking of the proposal by the panel, and the funding. This estimation does not deal with individual researchers' multiple proposals and funding over time. To disentangle these effects, we consider the $1500 \mathrm{New}$ Zealand researchers who appeared on any of these proposals, and estimate a model predicting annual individual performance as a function of previous performance, recent proposal activity, ranking of any recent proposals, and funding received through recent proposals. Overall, we find that funding is associated with a 6-15\% increase in publications and a $22-26 \%$ increase in citation-weighted papers for research teams. For individuals, funding is associated with a 3-5\% increase in annual publications, and a 5-8\% increase in citation-weighted papers for 5 years after grant; however, the lag structure and persistence of this effect post-grant is difficult to pin down. Surprisingly, we find no systematic evidence that the evaluation of proposals by the Marsden system is predictive of subsequent success. We conclude that the Marsden Fund is modestly successful in increasing scientific performance, but that the selection process does not appear to be effective in discriminating among second-round proposals in terms of their likely success.
\end{abstract}

Jason Gush

Royal Society of New Zealand

11 Turnbull St, Thorndon

Wellington 6011

New Zealand

jason.gush@royalsociety.org.nz

Adam B. Jaffe

Motu Economic and Public Policy Research

PO Box 24390

Wellington 6142

New Zealand

and Queensland University of Technology

and also NBER

adam.jaffe@motu.org.nz

\author{
Victoria Larsen \\ University of Otago \\ 362 Leith Street \\ North Dunedin, Dunedin 9016 \\ New Zealand \\ larvi165@student.otago.ac.nz
}

Athene Laws

Motu Economic and

Public Policy Research

PO Box 24390

Wellington 6142

New Zealand

athene.laws@gmail.com 


\section{Contents}

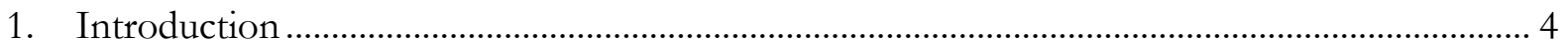

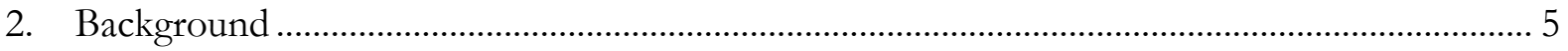

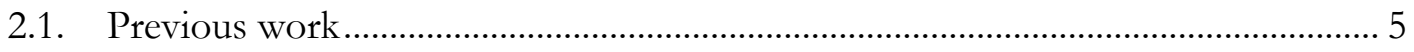

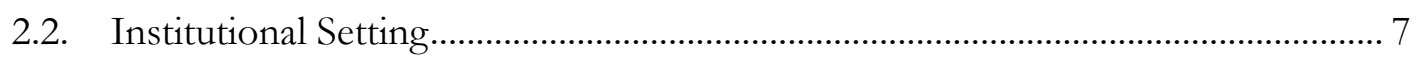

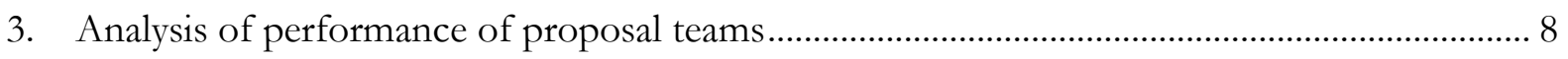

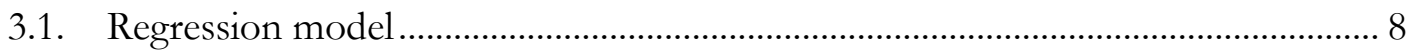

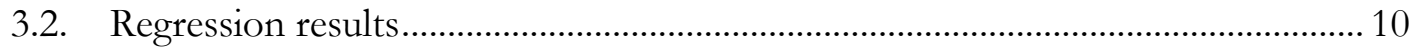

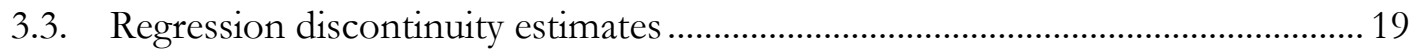

4. Modelling performance of individual researchers ........................................................................ 19

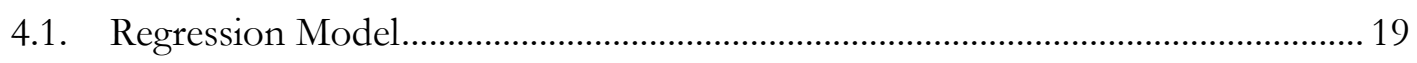

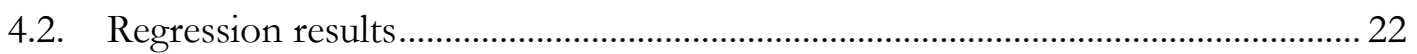

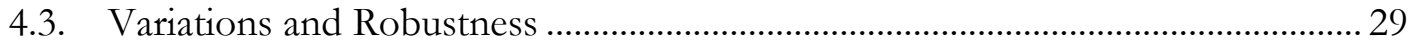

5. Summary and Conclusion ..................................................................................................... 32

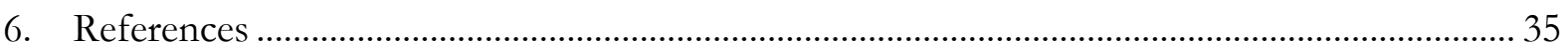

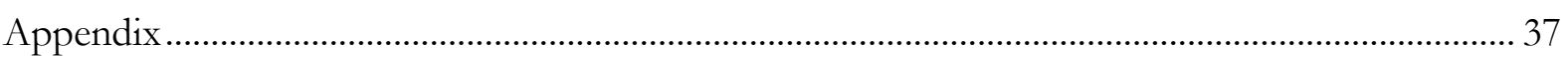

\section{Tables}

Table 1: Summary statistics on proposal-team dataset..................................................................... 11

Table 2: OLS Log-Log baseline regressions for proposal-team data .............................................. 12

Table 3: Negative Binomial baseline regressions for proposal-team data .......................................... 15

Table 4: Negative Binomial Regression variants on proposal-team data .......................................... 17

Table 5: Summary statistics on investigator-panel dataset.................................................................. 22

Table 6: Baseline results investigator-panel data .............................................................................. 23

Table 7: Comparison of selection metric - Zero inflated negative binomial regressions on investigator-panel data ....................................................................................................... 30

Table 8: Exploration of lag pattern - ZINB regressions on investigator-panel data ...................... 31

\section{Figures}

Figure 1: Relationship between residuals and scaled rank

Figure 2: Frequency distribution of preliminary $\left(1^{\text {st }}\right.$ stage $)$ proposals, full ( $2^{\text {nd }}$ stage $)$ proposals and contracts by investigator, 2000-2012 ................................................................................... 20

Figure 3: Hypothetical researcher under three funding scenarios .................................................... 28 


\section{Introduction}

There is a long history of programme evaluation in worker training and health delivery settings, but systematic evaluation of the effectiveness of government research support programmes is rare (Jaffe, 2002). While many research organizations tout the successes associated with their research grants, few make any serious effort to calculate how this rate of success compares to what would have occurred absent the programme's support, i.e. to calculate the "treatment effect" associated with receiving funding. Doing so requires comparing the success of grantees with that of a control group, and since the grants are explicitly made to those potential recipients judged most likely to succeed, any such comparison must control for selection bias.

The Marsden Fund is the premiere funding mechanism for basic research in New Zealand. It is funded by the government, but selection and administration is delegated to the Royal Society of New Zealand (RSNZ). With the intent to evaluate the Fund, the RSNZ has maintained records of the researchers associated with both successful and unsuccessful proposals, as well as the evaluation metrics (external referee scores, panel scores and panel ranks) of all of those proposals by the expert panels that form the basis of the funding decisions. This allows us to estimate the impact of receiving funding while controlling, via the evaluation scores, for the selectivity bias, separating the overall difference in success between the funded and unfunded teams into a selection effect and a treatment effect.

We look at the effects of the grant process on research output in two ways. First, we consider the researcher teams and look at the post-proposal publication and citation performance of the team as a whole, as a function of pre-proposal performance, the ranking of the proposal by the panel, and the funding received. We do this both with OLS and count model estimation of a parametric functional form for the relationship between research outputs and prior research outputs, Marsden funding, and the panel ranking, and with a non-parametric regression discontinuity design, simply comparing the success of the proposals just above the funding cutoff with the success of those just below the cut-off. Aggregating impacts in this way across team members and across years mitigates the inherent noisiness of publication output, and is robust to variations in the time lags between grant activity and scholarly output. But this approach cannot sort out the effect of multiple interactions with the Marsden programme on researchers' scholarly output over time. The average researcher on these teams made 6 proposals and received 1.2 grants 2000-2012. When we look at the post-proposal performance of a team-whether funded or not in a given round - it will typically include researchers who were also on other current or subsequent proposal teams, some of which were funded and some of which were not. To disentangle these effects, we consider all researchers who appeared on 
any of these proposals, and assemble their publications/citations, proposals, the evaluation of those proposals, and funding decisions on an annual basis. We estimate models on this panel predicting annual researcher performance as a function of previous performance, recent proposal activity, Marsden evaluations of any recent proposals, and funding received through recent proposals.

As a side-effect of estimating the parametric model of the selection and treatment effects, we learn something about how well the Marsden evaluation process predicts the future success of the proposals. The results suggest that receiving funding through the Marsden Fund does increase the success of the funded proposals, but that the various evaluations used to select funding recipients are themselves not systematically correlated with proposals' or researchers' subsequent performance. In other words, the study was constructed to separate the treatment effect from the selection effect, but in these data the selection effect does not seem to be present.

\section{Background}

\subsection{Previous work}

Arora et al. (2000) present a structural model with endogenous decisions by applicants and the granting agency. It evaluates the impact of funding from an Italian biotechnology programme using a large and comprehensive dataset of proposals to the biotechnology and bioinstrumentation programme from 1989 to 1993, using impact-factor-weighted publications as the measure of output. It found an estimated structural elasticity of research output with respect to the granted budget of about 0.6 but varying depending on research characteristics. This elasticity is estimated taking into account that previously successful researchers are more likely to be funded and, knowing this, request larger budget allocations.

Arora \& Gambardella (2005) study the impact of National Science Foundation (NSF) funding on economics researchers in the USA, comparing the research output of successful and unsuccessful applicants in a difference-in-difference framework. Using data from 1473 applications to the NSF from 1985 to 1990, they find that funding is associated with increased research output for younger economists, but not for senior applicants.

Jaffe (2002) (which was actually written after Arora and Gambardella (2005)) discusses the practicalities of different approaches to measuring the impact of public funding in the presence of selection bias, using as a benchmark the possibilty of a randomized control trial ("RCT"). It suggests that under typical grant programme circumstances, the regression- 
discontinuity approach introduced by Thistlethwaite \& Campbell (1960) provides almost as good an estimate of the funding effect as the realistic RCT formulation.

A closely related methodology was used by Jacob \& Lefgren (2011) to evaluate the impact of funding by the U.S. National Institute of Health (NIH) on research output. They compared successful and unsuccessful research proposals to the NIH from 1980 to 2000, using the priority scores from independent scientific reviews to control for selection bias. The NIH allocates funding in such a way that there is a highly non-linear relationship between priority scores and likelihood of being funded. This non-linearity is exploited in an instrumental variables framework to estimate the effect of funding purged of selectivity bias. Funding is associated with a $7 \%$ increase in publications over the 5-10 years post-funding. The IV and OLS estimates are qualitatively similar, suggesting that within this group of applying researchers the selectivity bias is not large. The authors argue that the small estimated effect is consistent with a model where the loss of an NIH grant is simply replaced by other sources of funding. They explore how being funded by the NIH affects future funding, and how non-NIH funded researchers are funded elsewhere. They find that most non-NIH funded researchers are funded elsewhere, and those who get NIH funding are less likely to receive NSF funding. This highlights the difference between the direct effect of a particular funding programme and its effect when viewed in interaction with other programmes. We return to this issue below.

Li and Agha (2015) looked at scientific outputs (papers, citations, patent citations) associated with more than 130,000 research project (R01) grants funded by the U.S. National Institutes of Health from 1980 to 2008. It finds that better peer-review scores are consistently associated with better research outcomes and that this relationship persists even after controlling for an investigator's publication history, grant history, institutional affiliations, career stage, and degree types. A one-standard deviation worse peer-review score among awarded grants is associated with $15 \%$ fewer citations, $7 \%$ fewer publications, $19 \%$ fewer high-impact publications, and $14 \%$ fewer follow-on patents. For high-impact publications, they try counts of publications in the top $5 \%, 1 \%$ and $.1 \%$ of all publications in the same year; they find predictive power for the referee score at all of these levels. This is the largest and most thorough study we identified of the predictive value of referee scores. It shows effects that are of modest but important size. Of course, in looking only at successful proposals, this work says nothing about the treatment effect.

Moving to the New Zealand and in particular the Marsden Fund context, a bibliometric analysis of the Fund was undertaken in 2001 comparing the number and impact of publications of Marsden Funded research teams to non-Marsden Funded publications (Knox (2004)). Across all fields, over the period 1997 to 2001 the Marsden Funded share of New Zealand authored 
publications rose from 2.2\% to 7.7\%. Marsden Funded publications were on average cited 1.7 times more than the non-Marsden Funded counterparts. As noted above, however, a study of this kind does not distinguish the extent to which the Marsden Fund is good at identifying the best research from the extent to which the receipt of funding increases research output.

\subsection{Institutional Setting}

The Marsden Fund was established in 1994 by the New Zealand Government to support New Zealand science on a competitive basis ${ }^{1}$. The fund is named after Sir Ernest Marsden, a prominent New Zealand born researcher who inspired physicist Ernest Rutherford to continue research into the structure of the atom. In 2013, \$67.9 million was allocated in research grants through the Marsden Fund. ${ }^{2}$ In a typical year, the Marsden Fund receives approximately 1000 proposals, and funds around 100 of those. The government delegates the administration of the programme, including the selection of grantees from among applicants, to the Royal Society of New Zealand (RSNZ), which was modelled after the Royal Society in Britain and is loosely analogous to the National Academy of Sciences (NAS) in the U.S. In this, the RSNZ acts on behalf of the Government-appointed Marsden Fund Council.

Proposal review is carried out by assessment panels of between 5 and 10 members appointed by the Royal Society. The overall budget is allocated to each panel by the RSNZ. Given the small size of the programme, each of these panels is rather broad in coverage; for example one is "Physical Sciences and Engineering" and one is "Economics and Human Behaviour." A list of the panels and their sizes over 2003-2008 is presented in the Appendix.

A proposal research team is made up of as few as one researcher, or as many as 8 . A team can be made up of Principle Investigators, Associate Investigators, Post Docs, Research Assistants/Technicians, and Post Graduate Students. The budget specifies the fraction of full time (FTE) that each investigator proposes to devote to the project. ${ }^{3}$ There are two types of grant given by the Marsden Fund. The standard grant is for any research team, and can run for up to three years. The maximum budget varied slightly by year and panel, but was on the order of NZD 300,000 per year. ${ }^{4}$ Applicants within 7 years of their $\mathrm{PhD}$ award have the option of apply for a "Fast-Start" ("FS") grant, which is limited to NZD 100,000 per year. FS proposals are ranked against other FS applicants rather than being compared with the general pool. Each panel decides how much of its allocated budget to use for FS and how much for the standard grants.

\footnotetext{
${ }^{1}$ http://www.royalsociety.org.nz/programmes/funds/marsden/about/background/

2 http://assets.royalsociety.org.nz/media/2014/07/Profiling-Excellence-2013-web.pdf

${ }^{3}$ Proposals can and do include investigators with zero FTE, i.e. they are associated with the project but will not be paid from the budget. In particular, non-New Zealand researchers can be included in proposals but cannot be paid from the proposal budget.

4 The NZD is worth approximately US\$0.65.
} 
The application process has two stages. A one-page initial proposal is reviewed by the panel without benefit of external referees. Each proposal is reviewed by a subset of the panel and given a preliminary score, based on the merit of the proposal and the potential of the project team. On this basis, the panels reject 71-84 percent of the proposals, with each panel deciding internally how many proposals to advance to the second stage. In the second stage, longer proposals are submitted and sent to external (including international) anonymous referees for review. Proponents are given an opportunity to respond to referee comments, and then the panels score these proposals based on the referee reports, the proponents' responses, their own judgment, and discussion within the panel. Each panel chooses a cutoff for regular proposals and a cutoff for Fast-start proposals, such that funding the proposals with rank above that cutoff fits within the allocated budget.

\section{Analysis of performance of proposal teams}

\subsection{Regression model}

This analysis is based on 1263 Marsden proposals from the second round reviews for the years $2003-2008$. Overall, $41 \%$ of the proposals were funded. About $25 \%$ of the proposals were Fast-Start proposals, and of these slightly more than half were funded. We measure the research success of each proposal team by identifying all of the publications of all team members, and all citations received by those publications, from 1995 through 2012. This information was collected from Scopus based on the researchers listed in the proposals appearing as publication authors. Thus we are not making any attempt to identify publications specifically related to the research as described in the proposal. We are simply investigating the relationship between researchers' overall research output and their participation in the Marsden process.

For each proposal $i$ submitted in year $t$, we consider the prior success of that research team to be proxied by their publications (or citations) received from 1995 until year $t-1$, and the subsequent success to be proxied by their publications (or citations) received from year $t+1$ through 2012. We capture the panel's subjective evaluation of each proposal (and control for selection bias) using its "scaled rank," defined as 1 minus the ratio of the integer ranking assigned by the panel (where the best proposal is assigned rank 1) to the total number of proposals ranked by the panel (i.e. lowest rank for that panel). Thus scaled rank is 0 for the lowest rank proposals and approaches unity $(1-1 / n)$ for the top ranked proposals. This scaling allows the rank to be comparable across panels in which different numbers of proposals were evaluated.

Our core analysis is based on the following variables: 


\section{Dependent variables}

Publications (annual)

Citations (annual)

$\log [($ publications +1$)]$

$\log [($ citations +1$)]$
The number of publications authored by members of the research team after the proposal, scaled by the number of years until 2012. i.e.

post proposal publications

2012-year

The number of citations to publications authored by members of the research team after the proposal, scaled by the number of years until

2012. i.e. $\frac{\text { post proposal citations }}{2012-y e a r}$

The natural log of post proposal publications as follows:

$\log \left(\frac{\text { post proposal publications }+1}{2012-y e a r}\right)$

The natural log of post proposal citations as follows:

$\log \left(\frac{\text { post proposal citations }+1}{2012-y e a r}\right)$

\section{Independent variables}

$\log ($ Past performance +1$)$

The natural log of publications or citations to publications authored by members of the research team before the proposal as follows: $\log \left(\frac{\text { pre proposal publications/citations }+1}{\text { year }-1996}\right)$

$\log ($ Past performance)

Dummy: Past

performance $=0$

Funded

Fast-Start

FS*Funded

Scaled Rank

Average referee score
The natural log of publications or citations to publications authored by members of the research team before the proposal, scaled by the number of years since 1996. If past publications/citations equals zero, this is set to zero. i.e.

$$
\log \left(\frac{\text { pre proposal performance }}{\text { year }-1996}\right) \text { if pre proposal performance } \geq 1
$$

$$
\text { if pre proposal performance }=0
$$

Dummy equals 1 if past performance (publications or citations) is zero. A dummy correction for Log(Past performance) to distinguish between those with no publications/citations and those with an average of one per year $(\log 1=0)$.

A dummy variable equal to 1 if the proposal was funded.

A dummy variable equal to 1 if the proposal was a Fast-Start proposal. An interaction term between 'Funded' and 'Fast-Start'

The panel rank the proposal received during the second round scaled by panel size. Ranges to 0 (lowest ranked) and approaches 1 (highest ranked)

The average external referee score received by the proposal during the second round. Ranges from 1 (top 5\% proposals) to 5 (below average). 
$\log ($ FTE $)$

Budget (NZ\$million)

FS*budget

Subsequent contract

Overdispersion: lnalpha

Panel Dummies

Time dummies
The natural log of the full time equivalent (FTE) of proposal investigators recorded in the proposal.

The size of the funded budget (in millions of NZ dollars).

An interaction term between 'Fast-Start' and 'Budget'.

A dummy variable equal to 1 if any member of the proposal team received funding from any year $\mathrm{t}+1$ to 2012 .

The natural log of alpha - the over-dispersion parameter associated with negative binomial regressions. Alpha equals 0 in a Poisson regression.

Nine panel dummies: equals 1 if proposal $i$ is submitted to the corresponding panel. 'BMS' is omitted from regressions.

Six year dummies: equals 1 if $\mathrm{t}$ equals the corresponding year. 2003 is omitted from regressions.

By including previous performance in the regression, we model success as likely to be persistent over time, with participants being on different success trajectories, but with the possibilities that the Marsden process shifts that trajectory. By including a dummy for Fast-Start proposals, we allow for the possibility that these (younger) investigators are on different trajectories than the average "Standard" proposal team. By including the interaction term between the Fast-Start dummy and the Funding dummy, we allow for the possibility that these younger investigators benefit differentially from the receipt of funding.

Panel dummies allow for the overall rate of publication and citation to differ across disciplines, and time dummies absorb the fact that the post-application intervals are of different durations for proposals from different years. We thereby assume that the proportional impact of Marsden funding is the same across fields and across observation periods of differing length. Finally, we include the dummy variable for subsequent funding because we are not attempting to identify the extent to which subsequent publications are directly tied to the research funded in the proposal whose effects we are trying to measure. For any given competitive round, there will be researchers, both among those funded and those rejected, who subsequently received funding from the Marsden programme in a subsequent competitive round. Since we measure publication success for all teams out to 2012, we would expect that this subsequent proposal activity could also be reflected in the overall subsequent performance of the teams.

\subsection{Regression results}

Descriptive statistics for the regression variables are presented in Table 1. Baseline OLS regression results using the log of performance-plus-one (scaled by the number of years pre or 
post submission) are presented in Table 2. The interpretation of all of the variable coefficients is the percentage increase in the performance measure, regardless of whether the base for that year and discipline is high or low. We add one to the publication and citation counts before taking logs because a very small number of observations have zero publications or zero citations either before or after the proposal round. We have also estimated the OLS log-log equations dropping the observations with zeros and the results are almost identical to those reported.

Table 1: Summary statistics on proposal-team dataset

\begin{tabular}{|l|rrrr|}
\hline Variable & \multicolumn{1}{|l}{ Mean } & Std.Dev. & Min & \multicolumn{1}{c|}{ Max } \\
\hline Past publications & 70.96041 & 71.26 & 0 & $>500$ \\
Future publications & 70.72051 & 66.57817 & 0 & $>400$ \\
Past citations & 2829.276 & 3594.865 & 0 & $>25000$ \\
Future citations & 1054.112 & 1480.084 & 0 & $>14000$ \\
Future publications per year & 11.31195 & 10.08695 & 0 & 63 \\
Past publications per year & 7.305418 & 7.027658 & 0 & 57.18182 \\
Future cites per year & 161.5095 & 203.414 & 0 & 1849.125 \\
Past cites per year & 292.7203 & 365.6876 & 0 & 2839 \\
Log(past pubs per year) & 1.442799 & 1.231489 & -2.48491 & 4.046236 \\
Log(past cites per year) & 4.619873 & 1.979748 & -2.48491 & 7.951207 \\
Scaled rank & 0.458334 & 0.28851 & 0 & 0.966667 \\
Funded & 0.408551 & 0.491761 & 0 & 1 \\
Fast Start & 0.249406 & 0.432841 & 0 & 1 \\
FS*Funded & 0.122724 & 0.32825 & 0 & 1 \\
Subsequent contract & 0.335709 & 0.472425 & 0 & 1 \\
Investigator FTE & 1.41563 & 1.003453 & 0 & 9.27 \\
budget & 0.180517 & 0.268883 & 0 & 1.243264 \\
budget (Funded subsample) & 0.441847 & 0.247939 & 0.041479 & 1.243264 \\
budget (Funded FS subsample) & 0.138839 & 0.055838 & 0.041479 & 0.302222 \\
\hline
\end{tabular}

\begin{tabular}{|l|r|}
\hline Percentage zeros & \% of teams \\
\hline No past publications & $3.40 \%$ \\
No past citations & $3.64 \%$ \\
No future publications & $1.58 \%$ \\
No future citations & $3.17 \%$ \\
\hline
\end{tabular}

Columns 1 and 4 present the simplest test for a funding effect, without attempting to correct for selection bias. They indicate that funding is associated with an increase in publications of about $6 \%$ and citations about $12 \%$ relative to what would have been predicted based on previous performance. The coefficient on previous performance is approximately .75 , and highly significant statistically, indicating that there is significant persistence in success but with some regression to the mean (coefficient less than unity). 
Columns 2 and 5 include the addition of the proposal's scaled rank, the Fast-Start dummy, the interaction term between Fast-Start and Funding, and the dummy for subsequent funding. The treatment effect associated with funding is increased to $15 \%$ for publications and $26 \%$ for citations. Fast-Start teams are associated with about $16 \%$ greater research output (controlling for pre-proposal performance), consistent with these younger investigators being, on average, on a steeper upward output trajectory than other researchers. The interaction term between Fast-Start and Funding is, however, essentially zero, indicating that there is no observable tendency for these younger researchers to benefit differentially from the receipt of funding.

Table 2: OLS Log-Log baseline regressions for proposal-team data

\begin{tabular}{|l|cccccc|}
\hline \multirow{4}{*}{ VARIABLES } & $(1)$ & $(2)$ & $(3)$ & $(4)$ & $(5)$ & $(6)$ \\
& Pubs & Pubs & $\Delta$ Pubs & Cites & Cites & $\Delta$ Cites \\
\hline \multirow{5}{*}{ Funded } & & & & & & \\
& $0.766^{* * *}$ & $0.787^{* * *}$ & & $0.733^{* * *}$ & $0.734^{* * *}$ & \\
Fast-Start & $(0.0144)$ & $(0.0156)$ & & $(0.0149)$ & $(0.0155)$ & \\
& $0.0638^{* *}$ & $0.145^{* * *}$ & $0.126^{* *}$ & $0.124^{* * *}$ & $0.264^{* * *}$ & $0.255^{* * *}$ \\
FS*Funded & $(0.0291)$ & $(0.0516)$ & $(0.0553)$ & $(0.0456)$ & $(0.0807)$ & $(0.0897)$ \\
& & $0.154^{* * *}$ & $0.329 * * *$ & & $0.159^{* *}$ & $0.412^{* * *}$ \\
Subsequent contract & & $(0.0465)$ & $(0.0480)$ & & $(0.0716)$ & $(0.0779)$ \\
& & 0.0327 & 0.0572 & & -0.0242 & -0.00149 \\
Scaled rank & & $(0.0645)$ & $(0.0691)$ & & $(0.101)$ & $(0.112)$ \\
& & $0.160 * * *$ & $0.0912 * * *$ & & $0.338^{* * *}$ & $0.222^{* * *}$ \\
Constant & & $(0.0328)$ & $(0.0348)$ & & $(0.0513)$ & $(0.0565)$ \\
& & $-0.214^{* * *}$ & $-0.217 * *$ & & $-0.293^{* *}$ & $-0.360^{* * *}$ \\
& & $(0.0798)$ & $(0.0856)$ & & $(0.125)$ & $(0.139)$ \\
Observations & & & & & & \\
R-squared & $0.554^{* * *}$ & $0.444 * * *$ & 0.0926 & $0.755^{* * *}$ & $0.583^{* * *}$ & $-0.806^{* * *}$ \\
& $(0.0627)$ & $(0.0658)$ & $(0.0650)$ & $(0.121)$ & $(0.125)$ & $(0.106)$ \\
\hline
\end{tabular}

Time and panel dummies included in all regressions

Standard errors in parentheses

${ }^{* * *} \mathrm{p}<0.01,{ }^{* *} \mathrm{p}<0.05,{ }^{*} \mathrm{p}<0.1$

The positive coefficient on the subsequent funding dummy is quite significant statistically. On average proposal teams (both those funded in the current round and those denied in the current round) that had a team member who received funding in some subsequent round received about $17 \%$ more publications and 35\% more citations than those that did not. It was this finding that led us to the investigator-year model discussed below.

The surprising result in columns 2 and 5 is that the coefficient on scaled rank is negative. This means that, controlling for the other regressors-including the effect of the funding itselfproposal teams that were highly ranked by the RSNZ panels actually performed worse than 
those that were ranked lower. Specifically, because the rank is scaled so that it is roughly one for the best-ranked proposal and zero for the worst, the coefficient of -.2 to -.3 means that the worst ranked proposal team got 20-30\% more output than the best team, after controlling for all other attributes, including previous performance. ${ }^{5}$

\section{Figure 1: Relationship between residuals and scaled rank}

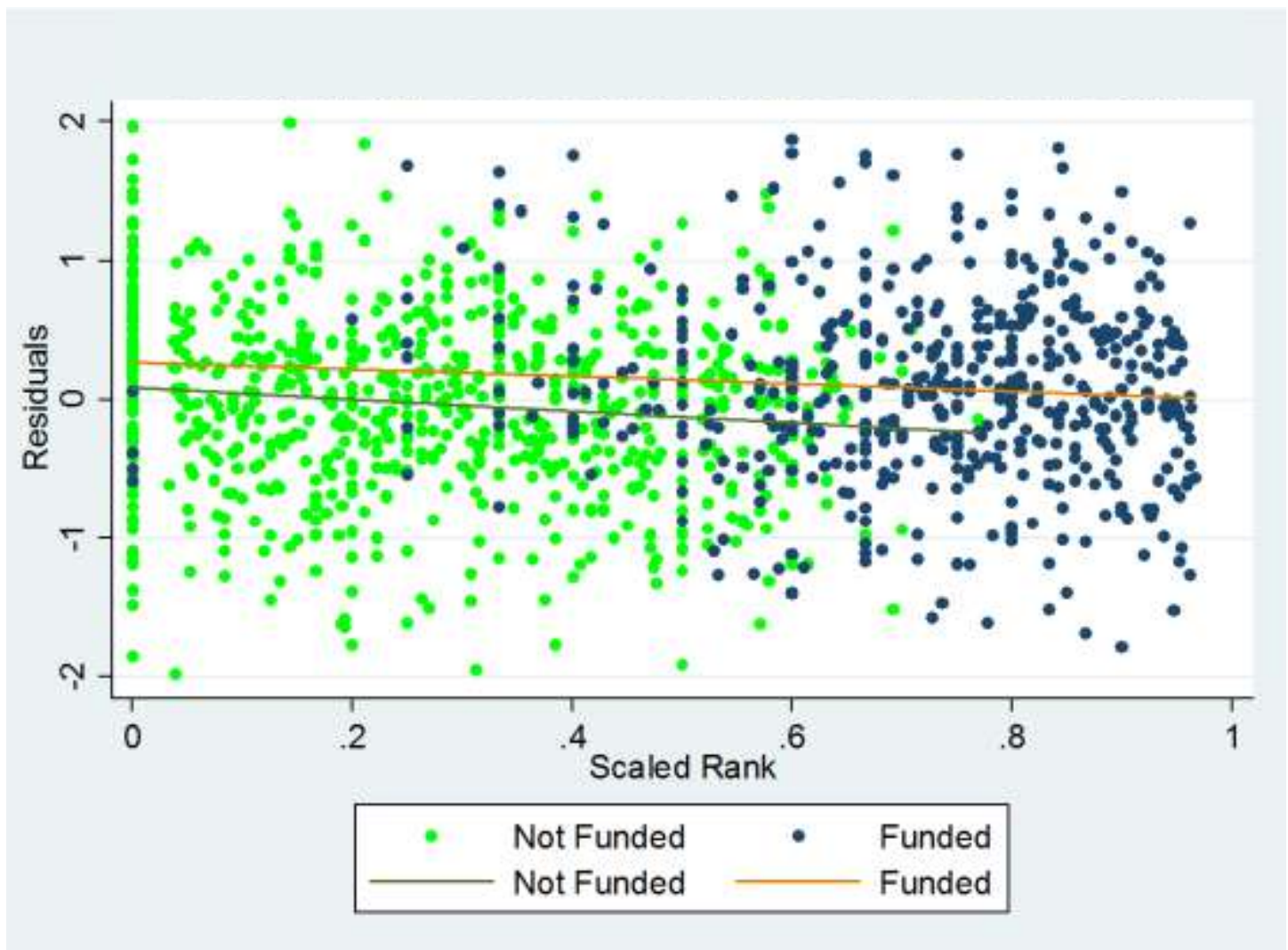

The combination of the funding and rank effects is shown graphically in Figure 1. To construct this Figure, the log-citations variable was regressed on year dummies, field dummies, and previous log-citations. The Figure then plots the residuals from this regression by scaled rank, and distinguishes those proposals that were funded from those that were not. These plotted points are therefore the post-proposal performance of each team, after taking out the effects of previous performance, year and discipline. The pattern is not particularly distinguishable by eye because the effect is small and the scatter is large, but the funded points

${ }^{5}$ If previous performance is excluded from the regression, the coefficient on scaled rank is essentially zero, suggesting that the negative estimate conditional on previous performance may reflect a tendency for panels to overweight past performance in predicting future performance. In order to ensure that the estimated lack of any positive selection effect is not an artifact of estimating the treatment and selection effects together, we also tried estimating the regressions in columns 2 and 5 of Table 2 separately for the unfunded and funded groups. The coefficient on scaled rank is negative for both groups in both regressions, but statistically significant only for the unfunded teams. 
are, on average, slightly higher than the unfunded points, and, at the same time, within both the funded and unfunded groups there is a slightly downward trend with rank. ${ }^{6}$

Columns 3 and 6 of Table 2 take the difference in the log-performance measure before and after the proposal round as the dependent variable. This corresponds to the regression in the previous column, except that the coefficient on previous performance is constrained to be unity. Since this constraint is strongly rejected by the data, we prefer the formulation where the relationship between ex post and ex ante performance is allowed to be determined by the data. But we show the constrained version as well because it corresponds to the "difference in difference" estimator of the funding effect, which is frequently used in this context (e.g. Arora and Gambardella, 2005). The estimated effects are all qualitatively similar to those in the previous column, with the exception of the Fast-Start effect, which is about twice as big in the difference formulation. This makes sense: the Fast-Start applicants have lower previous performance; when we constrain previous performance to have a unitary impact on subsequent performance their ex post performance is under-predicted; the increase in the Fast-Start dummy compensates for this and so fits the data better.

Table 3 converts these regressions into a more formal count data framework. The dependent performance variable is left in raw form - count of publications or citations to these publications, scaled by the number of years until 2012. The scaling factor does result in some non-integer dependent variable observations which is not strictly a count. However, the models perform well, and produce similar results to unscaled counts. ${ }^{7}$ For the independent variable, we take the natural log of past performance and set this equal to zero if past performance equals zero. To distinguish between observations with past performance equals one $(\log 1=0)$ and those where the $\log$ has been manually set to zero, we include a dummy correction equal to one if past performance is zero. It was found that conditional over-dispersion in our data warranted the use of a negative binomial model rather than a Poisson model, as the latter constrains the variance to equal the mean. While not precisely correct, the resulting coefficients are approximately equal to percentage effects for small changes.

${ }^{6}$ There are visible in the figure a handful of zero-rank proposals that were nonetheless funded. This is because the Fast-Start proposals are ranked separately from the regular proposals, and in a couple of instances panels received very few Fast-Start proposals and chose to fund them all.

${ }^{7}$ Horton, Kim and Saitz (2007) have argued that non-integer scaled values for dependent variables do not create a practical problem for count model estimation. 
Table 3: Negative Binomial baseline regressions for proposal-team data

\begin{tabular}{|c|c|c|c|c|}
\hline VARIABLES & $\begin{array}{l}\text { (1) } \\
\text { Pubs }\end{array}$ & $\begin{array}{l}\text { (2) } \\
\text { Pubs }\end{array}$ & $\begin{array}{c}(3) \\
\text { Cites }\end{array}$ & $\begin{array}{c}(4) \\
\text { Cites }\end{array}$ \\
\hline \multicolumn{5}{|l|}{ Count regression: } \\
\hline Log(past performance) & $\begin{array}{c}0.727^{* * *} \\
(0.0155)\end{array}$ & $\begin{array}{c}0.747 * * * \\
(0.0167)\end{array}$ & $\begin{array}{c}0.636^{* * *} \\
(0.0151)\end{array}$ & $\begin{array}{c}0.663 * * * \\
(0.0162)\end{array}$ \\
\hline Dummy: Past performance $=0$ & $\begin{array}{c}-1.947 * * * \\
(0.279)\end{array}$ & $\begin{array}{c}-1.990^{* * *} \\
(0.279)\end{array}$ & $\begin{array}{c}-1.472^{* * *} \\
(0.235)\end{array}$ & $\begin{array}{c}-1.421 \text { *** } \\
(0.232)\end{array}$ \\
\hline Funded & $\begin{array}{c}0.0256 \\
(0.0256)\end{array}$ & $\begin{array}{c}0.0644 \\
(0.0454)\end{array}$ & $\begin{array}{c}0.159 * * * \\
(0.0417)\end{array}$ & $\begin{array}{c}0.222^{* * *} \\
(0.0730)\end{array}$ \\
\hline Fast-Start & & $\begin{array}{c}0.132^{* * *} \\
(0.0460)\end{array}$ & & $\begin{array}{c}0.170^{* *} \\
(0.0668)\end{array}$ \\
\hline FS*Funded & & $\begin{array}{c}0.0401 \\
(0.0645)\end{array}$ & & $\begin{array}{c}0.113 \\
(0.0936)\end{array}$ \\
\hline Scaled rank & & $\begin{array}{c}-0.114 \\
(0.0722)\end{array}$ & & $\begin{array}{c}-0.237^{* *} \\
(0.115)\end{array}$ \\
\hline Subsequent contract & & $\begin{array}{c}0.0863^{* * *} \\
(0.0291)\end{array}$ & & $\begin{array}{c}0.313^{* * *} \\
(0.0452)\end{array}$ \\
\hline Constant & $\begin{array}{c}0.787 * * * \\
(0.0599)\end{array}$ & $\begin{array}{c}0.695^{* * *} \\
(0.0638)\end{array}$ & $\begin{array}{c}1.720^{* * *} \\
(0.116)\end{array}$ & $\begin{array}{c}1.371^{* * *} \\
(0.124)\end{array}$ \\
\hline Overdispersion: lnalpha & & & & \\
\hline Constant & $\begin{array}{c}-2.555^{* * *} \\
(0.0928) \\
\end{array}$ & $\begin{array}{c}-2.594 * * * \\
(0.0941) \\
\end{array}$ & $\begin{array}{c}-0.779 * * * \\
(0.0413) \\
\end{array}$ & $\begin{array}{c}-0.840 * * * \\
(0.0416) \\
\end{array}$ \\
\hline Observations & 1,263 & 1,263 & 1,263 & 1,263 \\
\hline Log likelihood & -3367 & -3351 & -6669 & -6632 \\
\hline
\end{tabular}

Time and panel dummies included in all regressions Standard errors in parentheses ${ }^{* * *} \mathrm{p}<0.01,{ }^{* *} \mathrm{p}<0.05,{ }^{*} \mathrm{p}<0.1$

Many of these regression findings are comparable to those from Table 2. Performance demonstrates persistent but mean reverting success with a coefficient on past performance of around 0.75 for publications and 0.65 for citations. The dummy correction is strongly negative indicating that those teams with past performance equals zero are expected to produce less in the future than those team with past performance equal to one. Fast-Start has a positive coefficient of 0.13 for publications and 0.17 for citations, while the interaction term is statistically zero younger investigators are still found to be on a steeper upward trajectory than their more senior counterparts but do not benefit differentially from funding. A team member receiving a subsequent contract is still associated with a positive and statistically significant increase in future performance. The coefficient on scaled rank remains negative and significant for citations, but loses significance for publications. The adjustment of most note is that the effect of receiving funding is no longer significant for publications, however for citations a coefficient of 0.16 to 0.22 remains significant at the $1 \%$ level. 
Table 4 tests the robustness of these results to some alternative model specifications. To conserve space we show these variations only for the citations performance measure, but results for publications are analogous. Using scaled rank to control for selection bias relies on an assumption about the functional form of the relationship between rank and performance; there is of course no reason why that relationship should be linear. Acting on the prior that panels might be able to identify very strong applicants and/or very weak applicants, but struggle to rank those in between, we replace scaled rank with two dummies in column one: high scaled rank equals one if the proposal received a scaled rank of 0.9 or higher, and low scaled rank if the rank was 0.2 or below. Neither had significant coefficients and so this does not appear to be a fruitful direction.

The argument for including scaled rank in the regression was to control for a selection effect, but that argument assumes that rank is positively associated with performance. Given that we find a negative relationship between rank and performance, it is less clear that the best way to test for a funding effect is after controlling for the relationship between rank and performance. Further, if the "true" relationship between rank and performance is non-linear, then the finding of a negative rank effect and a positive funding effect might simply reflect a negative rank effect that operates only over low rank but not higher rank. To explore this issue, Column two of Table 4 simply drops rank from the regression entirely. The effect is, again, to reduce the estimated treatment effect to about 0.11 although it remains highly significant statistically. This suggests that the estimated funding effect is not solely an artefact of the negative relationship between performance and rank. As discussed further below, whether the "right" estimate for the funding effect is that with or without the rank variable in the regression is largely one of interpretation.

In column three we replace scaled rank with the average referee score which ranges from 1 (top $5 \%$ of proposals) to 5 (below average). There is some evidence in the international literature that panel discussions of collated referee scores worsen rather than improving the selection process. (Fogelholm, et al, 2012). We were therefore interested to see whether the unprocessed referee scores were more predictive of success than panel rank. The coefficient, however, is not significant. 
Table 4: Negative Binomial Regression variants on proposal-team data

\begin{tabular}{|c|c|c|c|c|c|c|}
\hline $\begin{array}{l}\text { VARIABLES } \\
\text { Count regression: }\end{array}$ & $\begin{array}{l}(1) \\
\text { Cites }\end{array}$ & $\begin{array}{c}(2) \\
\text { Cites }\end{array}$ & $\begin{array}{c}(3) \\
\text { Cites }\end{array}$ & $\begin{array}{l}(4) \\
\text { Cites }\end{array}$ & $\begin{array}{c}(5) \\
\text { FTE*Cites }\end{array}$ & $\begin{array}{l}(6) \\
\text { Cites }\end{array}$ \\
\hline Log(Past performance) & $\begin{array}{c}0.663^{* * *} \\
(0.0162)\end{array}$ & $\begin{array}{c}0.661 * * * \\
(0.0162)\end{array}$ & $\begin{array}{c}0.662^{* * *} \\
(0.0162)\end{array}$ & $\begin{array}{c}0.661 * * * \\
(0.0163)\end{array}$ & $\begin{array}{c}0.667 * * * \\
(0.0162)\end{array}$ & $\begin{array}{c}0.660^{* * *} \\
(0.0162)\end{array}$ \\
\hline Dummy: Past & & & & & & \\
\hline Perfort & $\begin{array}{c}-1.417 * * * \\
(0.232)\end{array}$ & $\begin{array}{c}-1.412 * * * \\
(0.232)\end{array}$ & $\begin{array}{c}-1.405^{* * *} \\
(0.232)\end{array}$ & $\begin{array}{c}-1.400^{* * *} \\
(0.232)\end{array}$ & $\begin{array}{c}-1.661^{* * *} \\
(0.269)\end{array}$ & $\begin{array}{c}-1.420^{* * *} \\
(0.232)\end{array}$ \\
\hline Funded & $\begin{array}{c}0.157^{* * *} \\
(0.0551)\end{array}$ & $\begin{array}{l}0.105^{* *} \\
(0.0466)\end{array}$ & $\begin{array}{c}0.146^{* * *} \\
(0.0539)\end{array}$ & $\begin{array}{c}0.220^{* * *} \\
(0.0729)\end{array}$ & $\begin{array}{c}0.210^{* * *} \\
(0.0723)\end{array}$ & \\
\hline Fast-Start & $\begin{array}{c}0.178^{* * *} \\
(0.0667)\end{array}$ & $\begin{array}{c}0.196^{* * *} \\
(0.0657)\end{array}$ & $\begin{array}{c}0.184 * * * \\
(0.0661)\end{array}$ & $\begin{array}{c}0.207 * * * \\
(0.0724)\end{array}$ & $\begin{array}{c}0.218^{* * *} \\
(0.0726)\end{array}$ & $\begin{array}{l}0.243^{* * *} \\
(0.0639)\end{array}$ \\
\hline FS*Funded & $\begin{array}{c}0.121 \\
(0.0951)\end{array}$ & $\begin{array}{c}0.118 \\
(0.0937)\end{array}$ & $\begin{array}{c}0.117 \\
(0.0936)\end{array}$ & $\begin{array}{c}0.110 \\
(0.0936)\end{array}$ & $\begin{array}{c}0.112 \\
(0.0942)\end{array}$ & \\
\hline Subsequent contract & $\begin{array}{c}0.309 * * * \\
(0.0451)\end{array}$ & $\begin{array}{c}0.305^{* * *} \\
(0.0451)\end{array}$ & $\begin{array}{c}0.307 * * * \\
(0.0451)\end{array}$ & $\begin{array}{c}0.309 * * * \\
(0.0453)\end{array}$ & $\begin{array}{c}0.308^{* * *} \\
(0.0450)\end{array}$ & $\begin{array}{r}0.303^{* * *} \\
(0.0453)\end{array}$ \\
\hline Dummy: High scaled rank & $\begin{array}{l}-0.0746 \\
(0.0882)\end{array}$ & & & & & \\
\hline Dummy: Low scaled rank & $\begin{array}{c}0.0797 \\
(0.0508)\end{array}$ & & & & & \\
\hline Average referee score & & & $\begin{array}{c}0.0528 \\
(0.0348)\end{array}$ & & & \\
\hline Scaled rank & & & & $\begin{array}{c}-0.230^{* *} \\
(0.115)\end{array}$ & $\begin{array}{l}-0.209^{*} \\
(0.114)\end{array}$ & $\begin{array}{l}-0.0958 \\
(0.107)\end{array}$ \\
\hline $\log (\mathrm{FTE})$ & & & & $\begin{array}{c}0.0478 \\
(0.0375)\end{array}$ & $\begin{array}{c}0.377 * * * \\
(0.0417)\end{array}$ & \\
\hline budget (NZ\$million) & & & & & & $\begin{array}{c}0.233^{* *} \\
(0.111)\end{array}$ \\
\hline FS*budget & & & & & & $\begin{array}{c}0.789 \\
(0.571)\end{array}$ \\
\hline Constant & $\begin{array}{c}1.290^{* * *} \\
(0.128)\end{array}$ & $\begin{array}{c}1.351^{* * *} \\
(0.123)\end{array}$ & $\begin{array}{c}1.192^{* * *} \\
(0.161)\end{array}$ & $\begin{array}{c}1.369 * * * \\
(0.123)\end{array}$ & $\begin{array}{c}1.330^{* * *} \\
(0.122)\end{array}$ & $\begin{array}{c}1.414^{* * *} \\
(0.124)\end{array}$ \\
\hline Overdispersion: Inalpha & & & & & & \\
\hline Constant & $\begin{array}{c}-0.840 * * * \\
(0.0416)\end{array}$ & $\begin{array}{c}-0.837 * * * \\
(0.0416)\end{array}$ & $\begin{array}{c}-0.839 * * * \\
(0.0416)\end{array}$ & $\begin{array}{c}-0.842 * * * \\
(0.0416)\end{array}$ & $\begin{array}{c}-0.863^{* * *} \\
(0.0418)\end{array}$ & $\begin{array}{r}-0.833^{* * *} \\
(0.0415)\end{array}$ \\
\hline & 1,263 & 1,263 & 1,263 & 1,262 & 1,262 & 1,263 \\
\hline Log likelihood & -6633 & -6634 & -6633 & -6628 & -6801 & -6637 \\
\hline
\end{tabular}

Time and panel dummies included in all regressions

Standard errors in parentheses

Regression 5 weights citations by the FTE of investigators stated in the proposal *** $\mathrm{p}<0.01, * * \mathrm{p}<0.05, * \mathrm{p}<0.1$ 
As noted above, we are measuring success in terms of the overall publication output of the proposal team members. But a researcher's participation in a Marsden proposal can range between zero FTE and full-time. One might think that the effect of participation in the Marsden process would be greatest for those researchers most involved in the proposal, which might be proxied by their FTE as stated in the proposal. Columns 4 and 5 of Table 4 investigate this possibility. In Column 4, we simply add the log of total budgeted FTE to the regression. Its effect is zero, although the estimated effect of funding increases in magnitude. In Column 5 , we change the dependent variable, weighting all of the citations received by papers authored by team members by total budgeted investigators FTE in the proposal. The coefficient on funding remains higher at $0.21, \log$ (FTE) unsurprisingly turns very significantly positive and yet the other coefficients barely change. These results would seem to suggest that at this team-aggregate level we cannot distinguish differential impact of funding based on the different funding levels of the team members. Note that foreign investigators included in proposals always have FTE of zero. Thus this variation excludes their publications and demonstrates that the findings are not significantly affected by how foreign investigators are treated.

Finally, Column 6 of Table 4 retains the basic structure of Table 3 Column 4 but replaces the dummy variable for receiving funding with the actual budgeted dollar amount (set to zero for those proposals that were not funded). The estimated coefficient of 0.233 corresponds, approximately, to funding of $\$ 1$ million NZD being associated with a $23 \%$ increase in citations. The nonlinear nature of the model precludes direct extrapolation to other budget amounts, but this is qualitatively similar to the other models given that the average grant over this period was about NZD 580K. Note that the Fast-Start-budget interaction term coefficient of .789 suggests that on average Fast-Start proposals get a much bigger boost per dollar than regular proposals, but this coefficient is very imprecisely estimated. Since overall winning Fast-Start proposals are given about one-third as much money as winning regular proposals, the previous result that they get about the same boost as regular proposals on a dummy-variable yes/no basis is also consistent with their getting a bigger boost per budget dollar, but the imprecision with which all of the Fast-Start effects is estimated makes it hard to make strong statements.

To this point, we have allowed each disciplinary pool to have its own average publication/citation level, but have constrained the other regressors to have the same effect across disciplines. Appendix Table 3 (publications) and Appendix Table 4 (citations) presents the results of estimating negative binomial regressions separately for each disciplinary panel or pool. Unfortunately, the results are extremely noisy. Although the effect of prior performance is .6 to .8 , for every panel, the other coefficients of interest are very imprecisely estimated and the point estimates vary a lot. The effect of funding on publications is positive and statistically significant 
only for Biomedical Sciences. For citations, Biomedical Sciences, Mathematics and Information Sciences and Social Sciences panels have statistically positive funding effects. The coefficient on scaled rank is negative and significant for several panels.

\subsection{Regression discontinuity estimates}

The advantage of the regression analysis described in the previous section is that it allows us to use all of the data on funded and unfunded proposals in the attempt to measure the effect of funding on research output. The disadvantage is that it is dependent on functional form assumptions to control for differences between the funded and unfunded proposals other than their funding status. Further, it assumes that the "treatment effect" associated with funding is the same for all proposals, whereas in reality very high-ranked and very low-ranked proposals might enjoy different benefits from receiving funding. An alternative is to use regressiondiscontinuity methods, which essentially estimate similar regressions to the models presented above, but utilize only those observations that fall in some pre-selected "bandwidth" around the cutoff point along the rank ordering (Benavente et al (2012)). This means that the results are less sensitive to functional form, and provide an accurate estimate of the "local" funding effect, i.e. the effect of funding on proposals that are near the funding margin.

We explored using this approach to estimate the Marsden funding effect, using bandwidth of 6 proposals on either side of the cutoff and the log-log specification from Table 2 . The results produce an estimate of about .12 for the funding effect, with a standard error of about .21. It appears that signal/noise ratio of this effect is too small to identify it with any precision using only the observations in the vicinity of the cutoff.

\section{Modelling performance of individual researchers}

\section{1. $\quad$ Regression Model}

We begin with all of the named investigators who appear on any of the proposals considered in the previous section. This is about 2300 individuals which we then restrict to New Zealand based researchers, bringing us to around 1500 individuals. We deem New Zealand researchers to be our sample of interest as they are financially eligible for Marsden grants and are more likely to repeatedly interact with the Fund. ${ }^{8}$ We then identified all of the first-round and second-round proposals (since 2000) and research contracts (since 1996) on which these researchers appeared. We have also captured the first round panel score, first round panel rank, second round referee scores, second round panel score and second round panel rank for all of

\footnotetext{
${ }^{8}$ Marsden Fund guidelines stipulate that overseas researchers may be members of proposal teams but are not eligible to receive funds.
} 
these proposals since 2003. We have assembled these data into a researcher-year panel, 19962012, incorporating their publication and citation record. Not surprisingly, many of these researchers participated in multiple proposals over that period and some of them received multiple grants. The overall frequency distribution of first and second round proposals and grants/contracts is shown in Figure 2. As can be seen, about $90 \%$ of these researchers submitted two or more preliminary proposals, $60 \%$ submitted two or more full proposals and $30 \%$ received two or more contracts from 2000-2012. This pattern motivates our decision to switch to a panel that allows for analysis of multiple proposal submissions and contract receipts.

Figure 2: Frequency distribution of preliminary $\left(1^{\text {st }}\right.$ stage $)$ proposals, full $\left(2^{\text {nd }}\right.$ stage $)$ proposals and contracts by investigator, 2000-2012

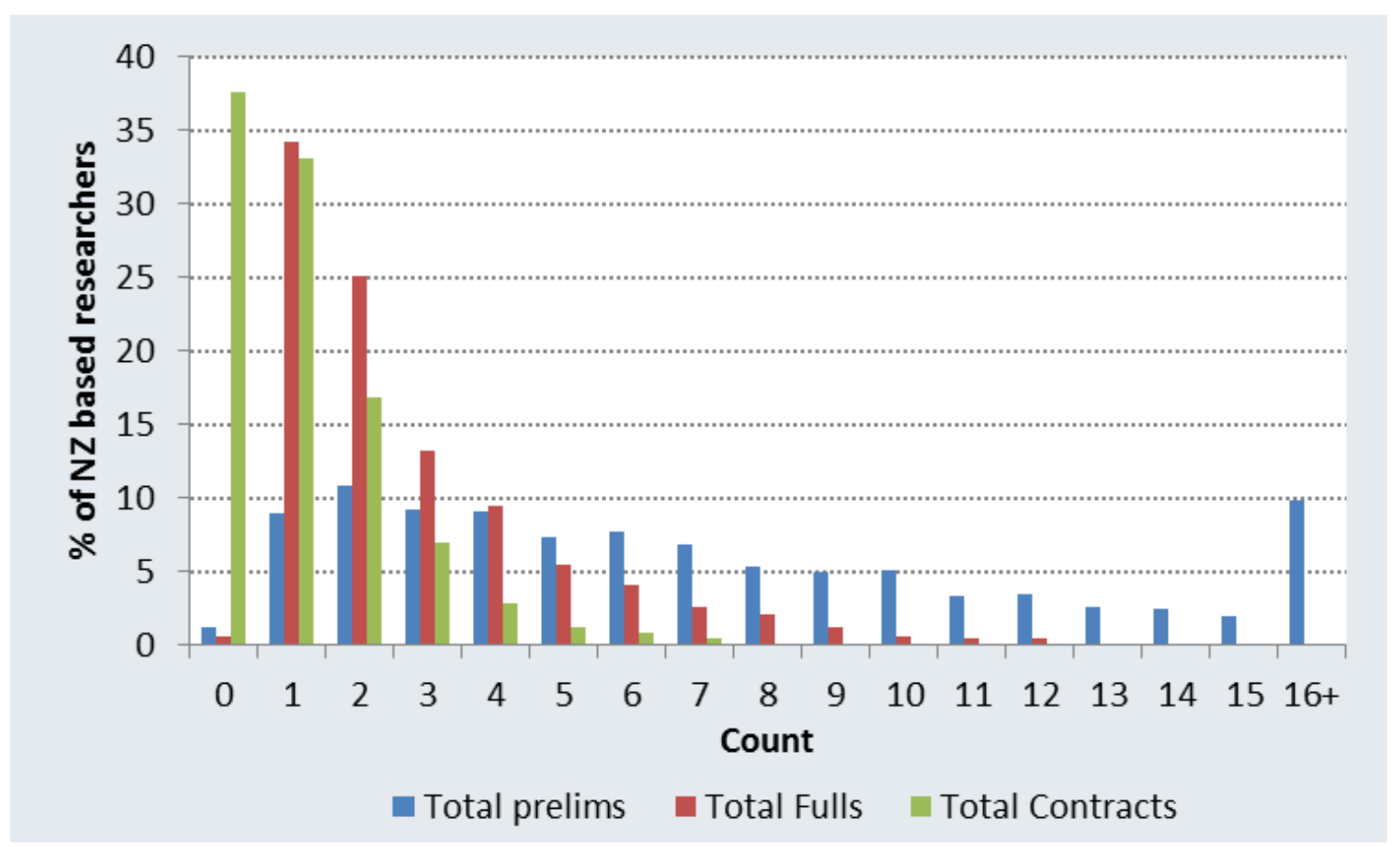

Sample: New Zealand based researchers who have submitted at least one full proposal.

In our regression analysis of these data, we restrict observations to only those individuals who have submitted second round proposals in the preceding five years. We do this so as to make this section analogous to the above proposal-team quasi-experimental approach and to reduce the noise associated with incorporating individuals who are no longer, or not yet, research active. We then regress a dynamic model of current performance (citations or publications) on past performance, past contracts and controls. We begin our timeframe in 2004 so as to allow for sufficient lags. The variables of interest are listed below:

\section{Dependent variables}

Publications

Normalised citations
The number of publications authored in time $\mathrm{t}$

The number of citations to publications authored in time $t$, normalised by panel and year. The mean of citations-per-publication was normalised to one for each panel in each year - this non-parametrically 


\section{Independent variables}

Log(Average Performance over past 5 years)

Dummy: Performance in past 5 years $=0$

Number of contracts in past five years

Best lagged scaled rank

Best lagged percent grade

Best lagged referee score

Years post degree

Dummy: Full FS in past five years

FS*Contracts in past 5 years

Panel Dummies

Time dummies adjusts for discipline heterogeneity and the phenomenon that older publications have longer time-frames to accrue citations.

The log of mean publications or mean normalised citations across t- 1 to $\mathrm{t}-5$. If the mean equals zero, the value is set to zero.

Dummy equals 1 if mean performance (publications or citations-peryear) across t- 1 to $t-5$ is zero. A dummy correction for $\log$ (Average Performance over past 5 years) to distinguish between those with no publications/normalised citations and those with an average of one per year $(\log 1=0)$.

The sum of contracts (funded proposals) received in t-1 to t-5.

The maximum scaled rank for a full (second stage) proposal in t-1 to t5. As per the research team regressions, this ranges from zero (lowest ranked in panel) and approaches unity (highest ranked in panel).

The maximum percentage grade for a full (second stage) proposal in t-1 to $\mathrm{t}-5$. Ranges from 0 to 100 .

The best (lowest) average referee score for a full (second stage) proposal in t-1 to t-5. Ranges from 1 to 5.

This is the number of years since the researcher received their highest degree (generally $\mathrm{PhD}$, excludes $\mathrm{MD}$ ) and can be conceptualised as professional age.

Dummy equals 1 if investigator submitted a full (second stage) FastStart proposal in $\mathrm{t}-1$ to $\mathrm{t}-5$.

Count of the number of contracts received in $\mathrm{t}-1$ to $\mathrm{t}-5$, if at least one FS proposal was submitted. Note: if an individual received a Fast-Start and a Standard contract during the same year both will be counted. Nineteen panel dummies: equals 1 if proposal $i$ is submitted to the corresponding panel. Twelve are for specific panels (e.g. MIS, ESA). Researchers involved in more than one panel during time $\mathrm{t}$ are classified in one of seven multidisciplinary panels. Details of the classification can be seen in the appendix. The panel dummy 'ALL' is omitted from regressions.

Nine year dummies: equals 1 if t equals the corresponding year. 2004 is omitted from regressions.

Table 5 presents descriptive statistics of these variables restricted to the sample of New Zealand based researchers who have submitted a full (second stage) proposal in the preceding five years $t=2004-2012$. As can be observed, about $25 \%$ of researcher-years have zero 
publications and around 30\% have zero citations. We therefore switch entirely to a count-data framework so as to avoid the log-log model that deals poorly with zeros.

Table 5: Summary statistics on investigator-panel dataset

Restricted to New Zealand based researchers who have submitted a full proposal in the preceding five years, 2004-2012.

\begin{tabular}{|l|rrrrr|}
\hline Variable & Mean & Std.Dev. & Min & Max & N \\
\hline Count publications & 3.135469 & 3.830887 & 0 & 46 & 9862 \\
Count cites to publications & 36.72034 & 90.65661 & 0 & 3134 & 9862 \\
Normalised citations & 3.609825 & 7.537339 & 0 & 182.5571 & 9862 \\
Mean normalised cites past 5 yrs & 3.153417 & 4.920935 & 0 & 80.91252 & 9862 \\
Mean pubs past 5 yrs & 2.72176 & 2.992051 & 0 & 28.2 & 9862 \\
Sum contracts past 5 yrs & 0.700061 & 0.777875 & 0 & 6 & 9862 \\
Max lag full grade past 5 yrs & 64.32144 & 22.96838 & 0 & 100 & 9862 \\
Max lag full rank past 5 yrs & 0.482743 & 0.311114 & 0 & 0.966667 & 9862 \\
Min referee grade past 5 yrs & 2.257098 & 0.968271 & 1 & 5 & 9862 \\
Log(Mean pubs past 5 yrs) & 0.591157 & 0.979442 & -1.60944 & 3.339322 & 9862 \\
Log(Mean norm cites past 5 yrs) & 0.488354 & 1.251274 & -4.97135 & 4.393369 & 9862 \\
Sum full proposals past 5 yrs & 1.734435 & 1.092492 & 1 & 8 & 9862 \\
Sum prelim proposals past 5 yrs & 3.792131 & 2.711005 & 0 & 26 & 9862 \\
\hline
\end{tabular}

\begin{tabular}{|l|r|}
\hline Percentage zeros & \multicolumn{1}{l|}{$\begin{array}{l}\text { \% of } \\
\text { researchers }\end{array}$} \\
\hline No publications time t & $24.69 \%$ \\
No citations time t & $30.71 \%$ \\
No publications in past 5 & \\
years & $8.48 \%$ \\
No citations past in 5 years & $9.89 \%$ \\
\hline
\end{tabular}

\subsection{Regression results}

We found that conditional over-dispersion in our data was inconsistent with the Poisson distributional assumption of equal mean and variance. A negative binomial distribution, which relaxes this assumption, was found to be a better fit for both citations and publications. 
Table 6: Baseline results investigator-panel data

$\mathrm{NB}=$ Negative binomial

NB FE = Negative binomial with fixed effects

ZINB $=$ Zero inflated negative binomial

\begin{tabular}{|c|c|c|c|c|}
\hline VARIABLES & $\begin{array}{l}(1) \\
\text { Pubs } \\
\text { NB }\end{array}$ & $\begin{array}{l}\text { (2) } \\
\text { Pubs } \\
\text { NB FE }\end{array}$ & $\begin{array}{c}(3) \\
\text { Pubs } \\
\text { ZINB }\end{array}$ & $\begin{array}{c}(4) \\
\text { Pubs } \\
\text { ZINB }\end{array}$ \\
\hline \multicolumn{5}{|l|}{ Count regression: } \\
\hline $\begin{array}{l}\text { Log(Average Performance over past } 5 \\
\text { years) }\end{array}$ & $\begin{array}{l}0.795^{* * *} \\
(0.0123)\end{array}$ & $\begin{array}{l}-0.135^{* * *} \\
(0.0232)\end{array}$ & $\begin{array}{l}0.791 * * * \\
(0.0139)\end{array}$ & $\begin{array}{l}0.796^{* * *} \\
(0.0139)\end{array}$ \\
\hline Dummy: Performance in past 5 years $=0$ & $\begin{array}{c}-2.036^{* * *} \\
(0.110)\end{array}$ & $\begin{array}{l}0.0927 \\
(0.123)\end{array}$ & $\begin{array}{c}-1.054 * * * \\
(0.232)\end{array}$ & $\begin{array}{c}-1.050^{* * *} \\
(0.233)\end{array}$ \\
\hline Number of contracts in past 5 years & $\begin{array}{c}0.0373 * * * \\
(0.0130)\end{array}$ & $\begin{array}{c}0.0453^{* * *} \\
(0.0158)\end{array}$ & $\begin{array}{c}0.0365^{* * *} \\
(0.0130)\end{array}$ & $\begin{array}{c}0.0341 * * \\
(0.0134)\end{array}$ \\
\hline FS*Contracts in past 5 years & $\begin{array}{l}- \\
-\end{array}$ & $\begin{array}{l}- \\
-\end{array}$ & - & $\begin{array}{l}-0.0148 \\
(0.0536)\end{array}$ \\
\hline Dummy: Full FS in past five years & $\begin{array}{l}- \\
-\end{array}$ & $\begin{array}{l}- \\
-\end{array}$ & $\begin{array}{l}- \\
-\end{array}$ & $\begin{array}{l}0.0959 * * \\
(0.0435)\end{array}$ \\
\hline Max lagged scaled rank & $\begin{array}{l}-0.0310 \\
(0.0408)\end{array}$ & $\begin{array}{l}-0.140 * * * \\
(0.0464)\end{array}$ & $\begin{array}{l}-0.0296 \\
(0.0409)\end{array}$ & $\begin{array}{l}-0.0226 \\
(0.0409)\end{array}$ \\
\hline Years post degree & $\begin{array}{l}-0.0009 * * * \\
(0.000304)\end{array}$ & $\begin{array}{c}-0.0003 \\
(0.00181)\end{array}$ & $\begin{array}{l}-0.0009 * * * \\
(0.000305)\end{array}$ & $\begin{array}{l}-0.0008^{* * *} \\
(0.000256)\end{array}$ \\
\hline Constant & $\begin{array}{r}0.153 \\
(0.202)\end{array}$ & $\begin{array}{l}2.530 * * * \\
(0.0913)\end{array}$ & $\begin{array}{c}0.161 \\
(0.202)\end{array}$ & $\begin{array}{c}0.161 \\
(0.204)\end{array}$ \\
\hline Overdispersion: lnalpha & & & & \\
\hline Constant & $\begin{array}{c}-1.683^{* * *} \\
(0.0509)\end{array}$ & $\begin{array}{c}2.530 * * * \\
(0.0913)\end{array}$ & $\begin{array}{c}-1.721 * * * \\
(0.0696)\end{array}$ & $\begin{array}{c}-1.730^{* * *} \\
(0.0674)\end{array}$ \\
\hline $\begin{array}{l}\text { Zero inflation regression } \\
\text { Log(Average Performance over past } 5 \\
\text { years) }\end{array}$ & $\begin{array}{l}- \\
-\end{array}$ & - & $\begin{array}{c}-0.708^{* * *} \\
(0.140)\end{array}$ & $\begin{array}{c}-0.702^{* * *} \\
(0.136)\end{array}$ \\
\hline Dummy: Performance in past 5 years $=0$ & - & - & $\begin{array}{c}5.337 * * * \\
(1.583)\end{array}$ & $\begin{array}{c}5.248^{* * *} \\
(1.360)\end{array}$ \\
\hline Constant & $\begin{array}{l}- \\
- \\
\end{array}$ & $\begin{array}{l}- \\
- \\
\end{array}$ & $\begin{array}{c}-4.028^{* * *} \\
(1.142) \\
\end{array}$ & $\begin{array}{c}-3.940 * * * \\
(0.981) \\
\end{array}$ \\
\hline $\begin{array}{l}\text { Observations } \\
\text { Log likelihood } \\
\text { N Researchers }\end{array}$ & $\begin{array}{c}9,843 \\
-18425\end{array}$ & $\begin{array}{c}9,193 \\
-13072 \\
1,439 \\
\end{array}$ & $\begin{array}{c}9,843 \\
-18407\end{array}$ & $\begin{array}{c}9,843 \\
-18400\end{array}$ \\
\hline
\end{tabular}

ZINB and NB regression errors are clustered around researchers

Time and panel dummies included in all count regressions

Time dummies included in all zero inflation regressions

Sample restricted to NZ based researchers with a full proposal in the previous 5 years

Robust standard errors in parentheses 
Table 6 Continued

\begin{tabular}{|c|c|c|c|c|}
\hline VARIABLES & $\begin{array}{l}(5) \\
\text { Cites } \\
\text { NB }\end{array}$ & $\begin{array}{c}(6) \\
\text { Cites } \\
\text { NB FE }\end{array}$ & $\begin{array}{c}(7) \\
\text { Cites } \\
\text { ZINB }\end{array}$ & $\begin{array}{c}(8) \\
\text { Cites } \\
\text { ZINB }\end{array}$ \\
\hline $\begin{array}{l}\text { Count regression: } \\
\text { Log(Average Performance over past } 5 \\
\text { years) }\end{array}$ & $\begin{array}{l}0.692^{* * *} \\
(0.0178)\end{array}$ & $\begin{array}{l}-0.0297 \\
(0.0190)\end{array}$ & $\begin{array}{l}0.675^{* * *} \\
(0.0175)\end{array}$ & $\begin{array}{l}0.676^{* * *} \\
(0.0175)\end{array}$ \\
\hline Dummy: Performance in past 5 years $=0$ & $\begin{array}{c}-2.097 * * * \\
(0.180)\end{array}$ & $\begin{array}{c}0.214 \\
(0.143)\end{array}$ & $\begin{array}{c}-0.518^{* *} \\
(0.259)\end{array}$ & $\begin{array}{l}-0.502 * \\
(0.258)\end{array}$ \\
\hline Number of contracts in past 5 years & $\begin{array}{l}0.0459 * \\
(0.0251)\end{array}$ & $\begin{array}{c}0.0724 * * * \\
(0.0220)\end{array}$ & $\begin{array}{l}0.0479 * \\
(0.0249)\end{array}$ & $\begin{array}{l}0.0551 * * \\
(0.0243)\end{array}$ \\
\hline FS*Contracts in past 5 years & - & - & - & $\begin{array}{c}-0.197 * \\
(0.103)\end{array}$ \\
\hline Dummy: Full FS in past five years & - & - & - & $\begin{array}{l}0.244^{* *} \\
(0.0970)\end{array}$ \\
\hline Max lagged scaled rank & $\begin{array}{l}0.0918 \\
(0.0733)\end{array}$ & $\begin{array}{l}-0.145^{* *} \\
(0.0648)\end{array}$ & $\begin{array}{r}0.0846 \\
(0.0723)\end{array}$ & $\begin{array}{c}0.105 \\
(0.0725)\end{array}$ \\
\hline Years post degree & $\begin{array}{l}-0.0010^{* * *} \\
(0.000214)\end{array}$ & - & $\begin{array}{l}-0.0009 * * * \\
(0.000219)\end{array}$ & $\begin{array}{c}-0.000879 * * * \\
(0.000198)\end{array}$ \\
\hline Constant & $\begin{array}{l}0.166 \\
(0.339)\end{array}$ & $\begin{array}{l}0.291 * * * \\
(0.0541)\end{array}$ & $\begin{array}{c}0.154 \\
(0.354)\end{array}$ & $\begin{array}{c}0.152 \\
(0.353)\end{array}$ \\
\hline $\begin{array}{l}\text { Overdispersion: Inalpha } \\
\text { Constant }\end{array}$ & $\begin{array}{c}0.0103 \\
(0.0402)\end{array}$ & $\begin{array}{c}0.291 * * * \\
(0.0541)\end{array}$ & $\begin{array}{c}-0.0966^{* *} \\
(0.0420)\end{array}$ & $\begin{array}{c}-0.100 * * \\
(0.0410)\end{array}$ \\
\hline $\begin{array}{l}\text { Zero inflation regression } \\
\text { Log(Average Performance over past } 5 \\
\text { years) }\end{array}$ & - & - & $\begin{array}{c}-0.831 * * * \\
(0.101)\end{array}$ & $\begin{array}{c}-0.832 * * * \\
(0.101)\end{array}$ \\
\hline Dummy: Performance in past 5 years $=0$ & - & - & $\begin{array}{c}9.297 * * * \\
(1.182)\end{array}$ & $\begin{array}{c}9.306^{* * *} \\
(1.181)\end{array}$ \\
\hline Constant & - & - & $\begin{array}{c}-6.381 * * * \\
(0.966)\end{array}$ & $\begin{array}{c}-6.378^{* * *} \\
(0.967)\end{array}$ \\
\hline $\begin{array}{l}\text { Observations } \\
\text { Log likelihood } \\
\text { N Researchers }\end{array}$ & $\begin{array}{c}9,843 \\
-20025\end{array}$ & $\begin{array}{c}8,944 \\
-14115 \\
1,394\end{array}$ & $\begin{array}{c}9,843 \\
-19844\end{array}$ & $\begin{array}{c}9,843 \\
-19833\end{array}$ \\
\hline
\end{tabular}

ZINB and NB regression errors are clustered around researchers

Time and panel dummies included in all count regressions

Time dummies included in all zero inflation regressions

Sample restricted to NZ based researchers with a full proposal in the previous 5 years

Robust standard errors in parentheses 
Table 6 presents our baseline negative binomial regressions. Columns one through three regress current publications on the log of past publications (set to zero with a dummy correction equal to one if publications equals zero), the maximum scaled rank received on a full proposal in the last five years, the professional age of the researcher and time and panel dummies under different distributional assumptions.

Column one performs a standard negative binomial regression and clusters the errors around researchers to account for a lack of independently distributed observations. We see similar estimates of the coefficient on previous performance to those in the proposal-team analysis: 0.8 and highly statistically significant, suggesting persistent success with some mean reversion. The estimate on the zero past performance dummy, as would be expected, is negative indicating that those who have not published in the recent past are likely to publish less than those who have published an average of once per year over the past five years. The coefficient of 0.0375 on contracts in the past five years, our estimated 'treatment' effect, can be approximately interpreted as each contract resulting in a publication rate in each of the subsequent 5 years $3.75 \%$ higher than it otherwise would have been. Professional age (years post degree) has a statistically significant but quantitatively negligible effect on publication counts and there is a small yet significant estimated degree of over-dispersion. Yet again, the maximum full scaled rank received in the past five years has no predictive ability holding all else constant.

Column two retains the same covariates and also incorporates researcher fixed effects, necessarily dropping those individuals with entirely zero outcomes in the process. Unsurprisingly, the coefficients on past performance change dramatically, as the individual fixed effect picks up most of the effect of lagged performance. The 'treatment' effect of receiving a contract increases slightly, although not significantly, to 0.045 suggesting that, if anything, omitting fixed effects provides a lower bound estimate of receiving funding. Our hypothesised control for selection bias, the maximum full scaled rank received in the past five years, turns negative and highly significant.

Column three presents a zero inflated negative binomial regression with clustered errors. This model simultaneously maximises the likelihood of a negative binomial count model and a model of excess zeros to account for the high percentage of dependent variable observations equalling zero. The estimated coefficients in the negative binomial count regression are very similar to those from column one, with the exception of the past performance dummy whose estimated effect halves. The zero inflation regression uses a logit model to predict the binary outcome of an individual researcher having strictly zero publications or being included in the count regression. The coefficients rather intuitively suggest that not publishing in the previous five years greatly increases the probability of not publishing in a given year and the stronger a 
researcher's average performance over the past five years, the less likely they will be unpublished in a given year. This model fits the data better than the non-zero-inflated version, but does not alter fundamentally the interpretation of the results.

Column four repeats column three's zero inflated negative binomial model but with the addition of two variables: a dummy for submitting a second stage 'Fast-Start' in the previous five years and a count of the contracts received while the researcher was a second stage 'Fast-Start' applicant in the previous five years. This fourth regression is analogous to the 'Fast-Start' interaction models presented in section III and the results are qualitatively similar. A second stage 'Fast-Start' applicant, irrespective of funding, is on a steeper publication growth trajectory than 'Standard' applicants but the incremental effect of receiving 'Fast-Start' funding over 'Standard' funding is statistically zero.

Columns five through eight repeat these specifications using citations to papers published in a given year, normalised by year and panel, as the performance metric. The simple negative binomial model in column five, as for publications, estimated strong persistent and mean reverting performance - as evidenced by a positive coefficient less than unity on past performance - and a strongly negative dummy correction for zero past citations. The impact of receiving a funded contract is estimated as an approximate $4.6 \%$ increase in annual citations for each of the subsequent five years, relative to what otherwise would have occurred. As this point estimate is higher than that for publications $(\sim 3.7 \%)$, it again suggests that the Marsden Fund modestly increases not only the quantity of publications but the average number of citations those publications receive. The maximum scaled full proposal rank received in the past five years remains statistically zero and professional age has a very minor estimated effect on citations per year.

The normalised citations negative binomial fixed effect model, presented in column 6, varies from the baseline negative binomial in a similar manner to that of the publications version. The removal of the fixed effects component markedly changes the coefficient estimates on past performance, and the estimated treatment effect of funding increases to $\sim 7.2 \%$ per year. The maximum scaled full rank remains statistically zero.

Columns seven and eight present zero inflated negative binomial models for citations per year. The estimates of the 'treatment' effect are similar to the negative binomial model in column 5 - funding generates a $5 \%$ to $5.5 \%$ increase in citations per year for the subsequent five years. As per the zero inflated logit model, an investigator with zero citations in the preceding five years is more likely to receive zero citations in the year in question and those with a recent history of more citations are less likely to be uncited. The addition of a 'Fast-Start' dummy and interaction with funding shows that 'Fast-Start' researchers are expected to be on a faster growth 
trajectory but the incremental effect of receiving a 'Fast-Start' grant, if anything, removes the funding effect (significant at the $10 \%$ level).

To assist with interpreting the effect of funding in the non-linear zero-inflated negative binomial model, Figure 3 uses regressions 4 and 8 to simulate a hypothetical researcher's output trajectory under three funding scenarios. In scenario A, the baseline case, the researcher never receives funding and produces just under 2 papers per year that receive a normalised citation count of around 1.5. In scenario B, the researcher receives a Marsden contract in 2003 only. For the next five years, $\mathrm{s} /$ he benefits from a direct boost in output in the order of $\sim 4 \%$ for publications and $\sim 6 \%$ for normalised citations. From 2005 onwards, s/he additionally experiences a positive indirect effect from the increase in the lagged performance covariate. As performance is persistent, but mean reverting, we see the total treatment effect persists after the direct has ended, but this boost gradually dies out over time. Effectively, receiving a grant pushes a researcher onto a higher output trajectory from which s/he only gradually reverts to baseline performance.

Our specification allows us to estimate the effects of multiple Marsden grants. Indeed, the mean researcher in our sample receives more than one grant, so scenario $\mathrm{C}$ simulates the cumulative effect of the researcher receiving a grant in 2003 and another in 2008. The impact of the second grant begins once the direct effect of the first finishes. The combined impacts of both grants results in a percentage increase over baseline for scenario $C$ that peaks in 2013 at $10 \%$ for publications and 14\% for normalised citations. Because we do not find heterogeneous treatment effects, and the model is close to proportional, these percentage differences should be qualitative similar across different researchers. 
Figure 3: Hypothetical researcher under three funding scenarios

Simulations of the Table 6 ZINB Regressions (columns 4 and 8)

Scenario A: No funding (baseline)

Scenario B: Funding in 2003

Scenario C: Funding in 2003 and 2008.

1: Simulated publication count trajectory, 1996-2016

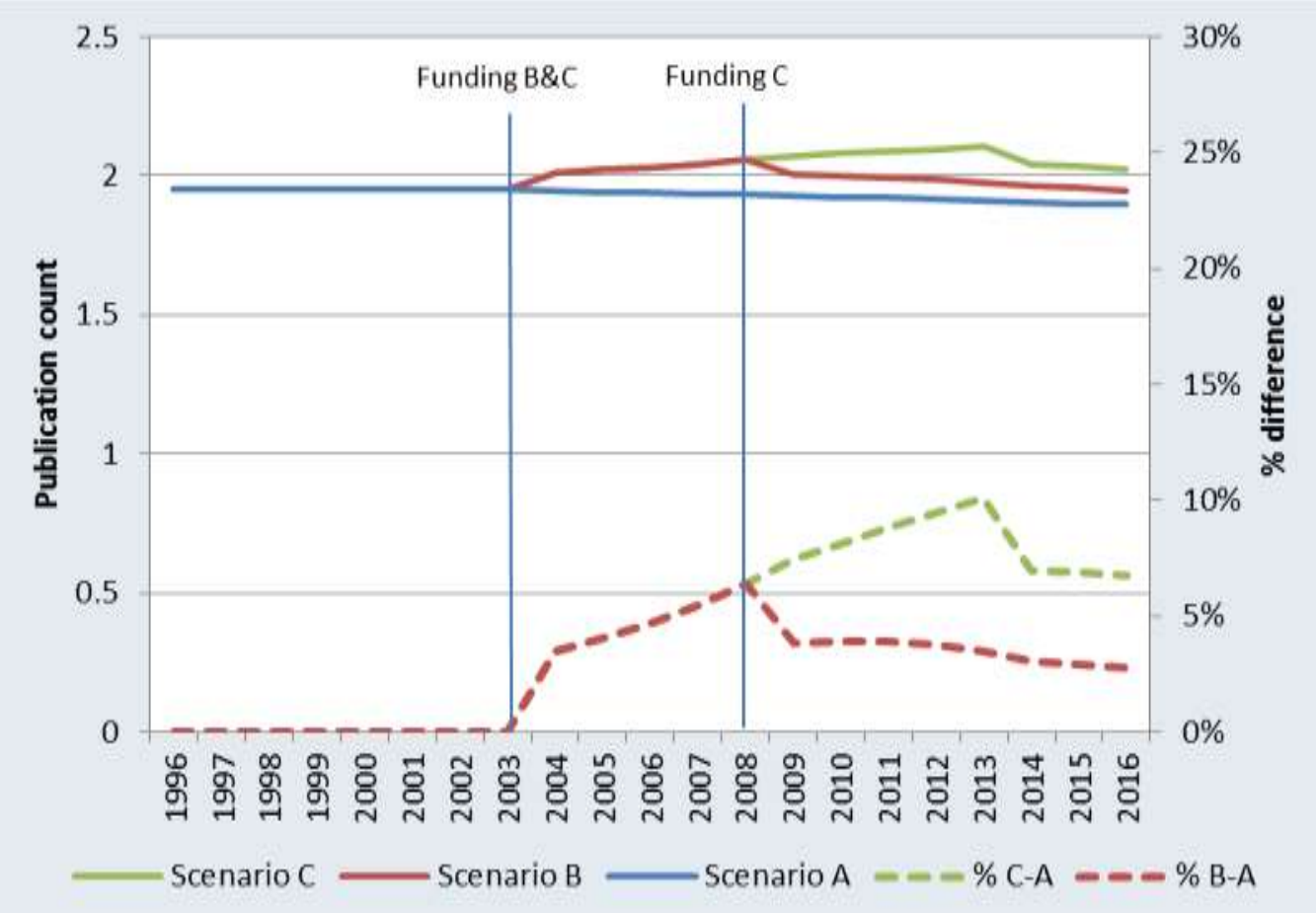

2: Simulated normalised citation count trajectory, 1996-2016.

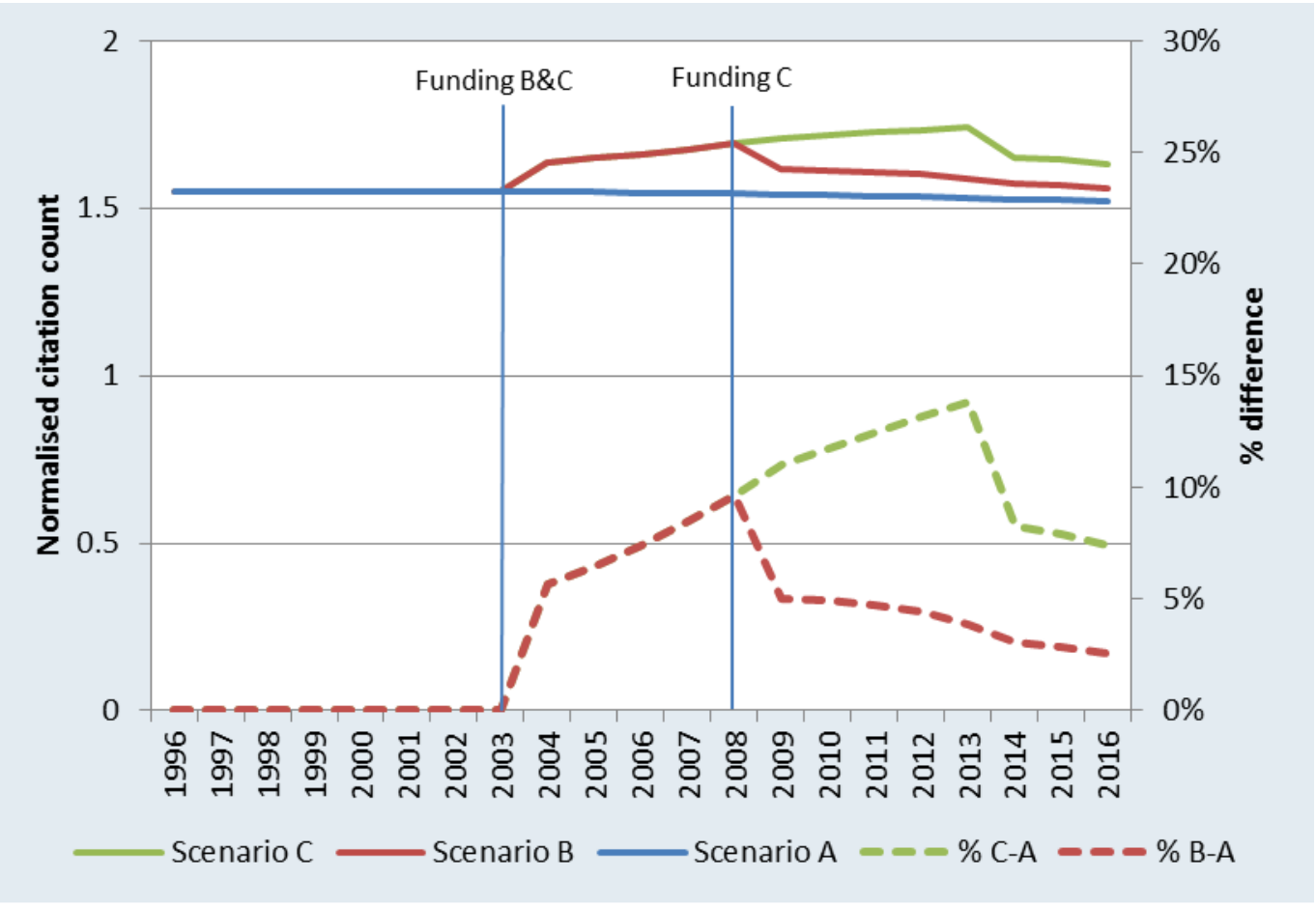




\subsection{Variations and Robustness}

Table 7 presents six zero inflated negative binomial models, three each for normalised citations and publications, that investigate various assessment metrics to control for selection bias. Columns one and four are the same as columns four and eight from Table 6 - they use the maximum scaled full rank received in the previous five years. Columns two and five switch to the maximum scaled full grade received in the past five years and columns three and six to the best average referee score of a full proposal in the past five years (note that 1 is the best grade and 5 the weakest). The coefficients change very little between the three publications regressions however the estimated treatment effect in terms of normalized citations increases when these alternate evaluation metrics are substituted for scaled rank. This illustrates that despite the absence of a clear selection effect, the magnitude of the estimated treatment effect is somewhat sensitive to conditioning in different ways on the programme's evaluation.

Table 8 includes four zero inflated negative binomial regressions with clustered errors that examine the lag structure of the dynamic panel and uncover some puzzling phenomena. Columns one and three, for publications and normalised citations respectively, separate the contracts received and the scaled ranks associated with full proposals by lags. When no full proposal was submitted in a given lag the scaled rank was set to zero and a dummy correction (not shown) was included to account for this. The lagged treatment effects are as one would expect. There is no impact of receiving a contract in the immediate year after funding however positive impacts on research output commence from the second year - $\sim 8 \%$ for publications and $\sim 20 \%$ for normalised citations. The lags are highly correlated potentially rendering the model unable to separately identify the impacts of contracts received in lag three (and lag four for citations). For both publications and citations, the fifth lag turns significantly positive - likely picking up a long tail of the funding effect. The coefficient on lagged scaled rank, noisy even when aggregated over the past five years, is unable to be significantly estimated when separated out beyond lag two.

Columns two and four, in response to a suspected long tail, move away from a five lag funding window and instead include as covariates the number of contracts received since 1996 and the maximum scaled full rank ever received since 2003. The estimated effect of funding disappears and even turns statistically negative in the case of publications. Overall, there just does not seem to be a strong enough signal/noise ratio to really get a handle on the time lags in the process. 
Table 7: Comparison of selection metric - Zero inflated negative binomial regressions on investigator-panel data

\begin{tabular}{|c|c|c|c|c|c|c|}
\hline VARIABLES & $\begin{array}{l}(1) \\
\text { Pubs }\end{array}$ & $\begin{array}{c}(2) \\
\text { Pubs }\end{array}$ & $\begin{array}{c}(3) \\
\text { Pubs }\end{array}$ & $\begin{array}{c}(4) \\
\text { Cites }\end{array}$ & $\begin{array}{c}(5) \\
\text { Cites }\end{array}$ & $\begin{array}{c}(6) \\
\text { Cites }\end{array}$ \\
\hline $\begin{array}{l}\text { Count regression: } \\
\text { Log(Average Performance over } \\
\text { past } 5 \text { years) }\end{array}$ & $\begin{array}{l}0.796^{* * *} \\
(0.0139)\end{array}$ & $\begin{array}{c}0.795^{* * *} \\
(0.0139)\end{array}$ & $\begin{array}{l}0.795^{* * *} \\
(0.0139)\end{array}$ & $\begin{array}{l}0.676^{* * *} \\
(0.0175)\end{array}$ & $\begin{array}{l}0.676^{* * *} \\
(0.0175)\end{array}$ & $\begin{array}{l}0.676^{* * *} \\
(0.0176)\end{array}$ \\
\hline $\begin{array}{l}\text { Dummy: Performance past } 5 \\
\text { yrs }=0\end{array}$ & $\begin{array}{c}-1.050 * * * \\
(0.233)\end{array}$ & $\begin{array}{c}-1.048^{* * *} \\
(0.233)\end{array}$ & $\begin{array}{c}-1.049 * * * \\
(0.233)\end{array}$ & $\begin{array}{l}-0.502^{*} \\
(0.258)\end{array}$ & $\begin{array}{l}-0.503^{*} \\
(0.258)\end{array}$ & $\begin{array}{l}-0.501 * \\
(0.259)\end{array}$ \\
\hline $\begin{array}{l}\text { Number of contracts in past } 5 \\
\text { years }\end{array}$ & $\begin{array}{c}0.0341 * * \\
(0.0134)\end{array}$ & $\begin{array}{l}0.0339 * * * \\
(0.0120)\end{array}$ & $\begin{array}{c}0.0315^{* * *} \\
(0.0114)\end{array}$ & $\begin{array}{l}0.0551 * * \\
(0.0243)\end{array}$ & $\begin{array}{l}0.0708^{* * *} \\
(0.0216)\end{array}$ & $\begin{array}{l}0.0794 * * * \\
(0.0211)\end{array}$ \\
\hline FS*Contracts in past 5 years & $\begin{array}{l}-0.0148 \\
(0.0536)\end{array}$ & $\begin{array}{l}-0.0145 \\
(0.0536)\end{array}$ & $\begin{array}{l}-0.0157 \\
(0.0537)\end{array}$ & $\begin{array}{c}-0.197 * \\
(0.103)\end{array}$ & $\begin{array}{c}-0.193^{*} \\
(0.102)\end{array}$ & $\begin{array}{l}-0.190 * \\
(0.102)\end{array}$ \\
\hline Dummy: Full FS in past 5 years & $\begin{array}{l}0.0959 * * \\
(0.0435)\end{array}$ & $\begin{array}{l}0.0969 * * \\
(0.0435)\end{array}$ & $\begin{array}{l}0.0969 * * \\
(0.0435)\end{array}$ & $\begin{array}{l}0.244^{* *} \\
(0.0970)\end{array}$ & $\begin{array}{l}0.238^{* *} \\
(0.0966)\end{array}$ & $\begin{array}{l}0.237 * * \\
(0.0962)\end{array}$ \\
\hline Max lag scaled rank & $\begin{array}{l}-0.0226 \\
(0.0409)\end{array}$ & & & $\begin{array}{c}0.105 \\
(0.0725)\end{array}$ & & \\
\hline Max lag percent grade & & $\begin{array}{l}-0.000389 \\
(0.000465)\end{array}$ & & & $\begin{array}{c}0.000676 \\
(0.000830)\end{array}$ & \\
\hline Best lag referee score & & & $\begin{array}{l}0.00586 \\
(0.0105)\end{array}$ & & & $\begin{array}{c}-0.000424 \\
(0.0210)\end{array}$ \\
\hline Years post degree & $\begin{array}{l}-0.0008^{* * *} \\
(0.000256)\end{array}$ & $\begin{array}{l}-0.0008^{* * *} \\
(0.000256)\end{array}$ & $\begin{array}{l}-0.0008^{* * *} \\
(0.000256)\end{array}$ & $\begin{array}{l}-0.0009^{* * *} \\
(0.000198)\end{array}$ & $\begin{array}{l}-0.0009 * * * \\
(0.000196)\end{array}$ & $\begin{array}{l}-0.0009 * * * \\
(0.000196)\end{array}$ \\
\hline $\begin{array}{l}\text { Constant } \\
\text { Overdispersion: lnalpha }\end{array}$ & $\begin{array}{c}0.161 \\
(0.204)\end{array}$ & $\begin{array}{c}0.166 \\
(0.204)\end{array}$ & $\begin{array}{c}0.138 \\
(0.209)\end{array}$ & $\begin{array}{r}0.152 \\
(0.353)\end{array}$ & $\begin{array}{c}0.134 \\
(0.351)\end{array}$ & $\begin{array}{c}0.135 \\
(0.366)\end{array}$ \\
\hline Constant & $\begin{array}{c}-1.730 * * * \\
(0.0674)\end{array}$ & $\begin{array}{l}-1.730 * * * \\
(0.0674)\end{array}$ & $\begin{array}{c}-1.730 * * * \\
(0.0672)\end{array}$ & $\begin{array}{l}-0.100^{* *} \\
(0.0410)\end{array}$ & $\begin{array}{c}-0.0998^{* *} \\
(0.0411)\end{array}$ & $\begin{array}{c}-0.0998^{* *} \\
(0.0412)\end{array}$ \\
\hline $\begin{array}{l}\text { Zero inflation regression } \\
\text { Log(Average Performance over }\end{array}$ & & & & & & \\
\hline past 5 years) & $\begin{array}{c}-0.702 * * * \\
(0.136)\end{array}$ & $\begin{array}{c}-0.700 * * * \\
(0.136)\end{array}$ & $\begin{array}{c}-0.700 * * * \\
(0.136)\end{array}$ & $\begin{array}{c}-0.832^{* * *} \\
(0.101)\end{array}$ & $\begin{array}{c}-0.832^{* * *} \\
(0.101)\end{array}$ & $\begin{array}{c}-0.833 * * * \\
(0.101)\end{array}$ \\
\hline $\begin{array}{l}\text { Dummy: Performance in past } 5 \\
\text { years }=0\end{array}$ & $\begin{array}{c}5.248^{* * *} \\
(1.360)\end{array}$ & $\begin{array}{c}5.246^{* * *} \\
(1.352)\end{array}$ & $\begin{array}{c}5.244 * * * \\
(1.344)\end{array}$ & $\begin{array}{c}9.306^{* * *} \\
(1.181)\end{array}$ & $\begin{array}{c}9.307 * * * \\
(1.181)\end{array}$ & $\begin{array}{c}9.305^{* * *} \\
(1.182)\end{array}$ \\
\hline Constant & $\begin{array}{c}-3.940 * * * \\
(0.981)\end{array}$ & $\begin{array}{c}-3.943^{* * *} \\
(0.975)\end{array}$ & $\begin{array}{c}-3.935^{* * *} \\
(0.970)\end{array}$ & $\begin{array}{c}-6.378^{* * *} \\
(0.967)\end{array}$ & $\begin{array}{c}-6.382^{* * *} \\
(0.967)\end{array}$ & $\begin{array}{c}-6.388 * * * \\
(0.968)\end{array}$ \\
\hline $\begin{array}{l}\text { Observations } \\
\text { Log likelihood }\end{array}$ & $\begin{array}{c}9,843 \\
-18400\end{array}$ & $\begin{array}{c}9,843 \\
-18400\end{array}$ & $\begin{array}{c}9,843 \\
-18400\end{array}$ & $\begin{array}{c}9,843 \\
-19833\end{array}$ & $\begin{array}{c}9,843 \\
-19834\end{array}$ & $\begin{array}{c}9,843 \\
-19835\end{array}$ \\
\hline
\end{tabular}

Regression errors are clustered around researchers

Time and panel dummies included in all count regressions

Time fixed dummies included in all zero inflation regressions

Sample restricted to NZ based researchers with a full proposal in the previous 5 years

Robust standard errors in parentheses 
Table 8: Exploration of lag pattern - ZINB regressions on investigator-panel data

\begin{tabular}{|c|c|c|c|c|}
\hline VARIABLES & $\begin{array}{l}\text { (1) } \\
\text { Pubs }\end{array}$ & $\begin{array}{l}\text { (2) } \\
\text { Pubs }\end{array}$ & $\begin{array}{c}(3) \\
\text { Cites } \\
\end{array}$ & $\begin{array}{l}(4) \\
\text { Cites }\end{array}$ \\
\hline \multicolumn{5}{|l|}{$\begin{array}{l}\text { Count regression: } \\
\text { Log(Average Performance over past } 5\end{array}$} \\
\hline $\begin{array}{l}\text { Log(Average Performance over past } 5 \\
\text { years) }\end{array}$ & $\begin{array}{l}0.791 * * * \\
(0.0143)\end{array}$ & $\begin{array}{l}0.796 * * * \\
(0.0138)\end{array}$ & $\begin{array}{l}0.668^{* * *} \\
(0.0208)\end{array}$ & $\begin{array}{l}0.674 * * * \\
(0.0210)\end{array}$ \\
\hline Dummy: Performance in past 5 years $=0$ & $\begin{array}{c}-1.047 * * * \\
(0.233)\end{array}$ & $\begin{array}{c}-1.063 * * * \\
(0.232)\end{array}$ & $\begin{array}{c}-0.548^{* *} \\
(0.267)\end{array}$ & $\begin{array}{c}-0.544 * * \\
(0.265)\end{array}$ \\
\hline Contracts lag 1 & $\begin{array}{l}-0.00712 \\
(0.0385)\end{array}$ & & $\begin{array}{c}0.0168 \\
(0.0827)\end{array}$ & \\
\hline Contracts lag 2 & $\begin{array}{l}0.0814 * * \\
(0.0332)\end{array}$ & & $\begin{array}{l}0.193 * * * \\
(0.0600)\end{array}$ & \\
\hline Contracts lag 3 & $\begin{array}{c}0.0288 \\
(0.0294)\end{array}$ & & $\begin{array}{c}0.0183 \\
(0.0558)\end{array}$ & \\
\hline Contracts lag 4 & $\begin{array}{l}0.0595^{* *} \\
(0.0299)\end{array}$ & & $\begin{array}{l}0.00500 \\
(0.0536)\end{array}$ & \\
\hline Contracts lag 5 & $\begin{array}{l}0.0598 * * \\
(0.0272)\end{array}$ & & $\begin{array}{l}0.0976^{*} \\
(0.0515)\end{array}$ & \\
\hline Numbers of contracts since 1996 & & $\begin{array}{l}-0.0166 * * \\
(0.00804)\end{array}$ & & $\begin{array}{l}0.00971 \\
(0.0139)\end{array}$ \\
\hline max scaled rank lag 1 & $\begin{array}{l}-0.0305 \\
(0.0752)\end{array}$ & & $\begin{array}{c}-0.0345 \\
(0.151)\end{array}$ & \\
\hline max scaled rank lag 2 & $\begin{array}{l}-0.166^{* *} \\
(0.0690)\end{array}$ & & $\begin{array}{l}-0.212^{*} \\
(0.115)\end{array}$ & \\
\hline max scaled rank lag 3 & $\begin{array}{l}0.00713 \\
(0.0633)\end{array}$ & & $\begin{array}{c}0.117 \\
(0.111)\end{array}$ & \\
\hline max scaled rank lag 4 & $\begin{array}{l}-0.0756 \\
(0.0617)\end{array}$ & & $\begin{array}{l}0.0695 \\
(0.127)\end{array}$ & \\
\hline max scaled rank lag 5 & $\begin{array}{l}-0.0518 \\
(0.0663)\end{array}$ & & $\begin{array}{l}-0.0326 \\
(0.120)\end{array}$ & \\
\hline $\begin{array}{l}\text { max scaled rank since } 2003 \text { (records } \\
\text { began) }\end{array}$ & & $\begin{array}{c}0.0444 * * * \\
(0.0171)\end{array}$ & & $\begin{array}{c}0.0307 \\
(0.0295)\end{array}$ \\
\hline Years post degree & $\begin{array}{l}-0.0008 * * * \\
(0.000292)\end{array}$ & $\begin{array}{l}-0.0008 * * * \\
(0.000287)\end{array}$ & $\begin{array}{r}-0.0009 * * * \\
(0.000213)\end{array}$ & $\begin{array}{l}-0.0010^{* * *} \\
(0.000221)\end{array}$ \\
\hline Constant & $\begin{array}{c}0.323 \\
(0.215)\end{array}$ & $\begin{array}{c}0.205 \\
(0.208)\end{array}$ & $\begin{array}{c}0.270 \\
(0.366)\end{array}$ & $\begin{array}{c}0.187 \\
(0.354)\end{array}$ \\
\hline Overdispersion: lnalpha & & & & \\
\hline Constant & $\begin{array}{c}-1.719 * * * \\
(0.0736)\end{array}$ & $\begin{array}{c}-1.724 * * * \\
(0.0666)\end{array}$ & $\begin{array}{l}-0.106^{* *} \\
(0.0435)\end{array}$ & $\begin{array}{c}-0.0995^{* *} \\
(0.0428)\end{array}$ \\
\hline $\begin{array}{l}\text { Zero inflation regression } \\
\text { Log(Average Performance over past } 5\end{array}$ & & & & \\
\hline years) & $\begin{array}{c}-0.704 * * * \\
(0.144)\end{array}$ & $\begin{array}{c}-0.709 * * * \\
(0.133)\end{array}$ & $\begin{array}{c}-0.958^{* * *} \\
(0.156)\end{array}$ & $\begin{array}{c}-0.951 * * * \\
(0.159)\end{array}$ \\
\hline Dummy: Performance in past 5 years $=0$ & $\begin{array}{c}5.648^{* *} \\
(2.353)\end{array}$ & $\begin{array}{c}5.230^{* * *} \\
(1.332)\end{array}$ & $\begin{array}{c}6.363^{* * *} \\
(1.911)\end{array}$ & $\begin{array}{c}6.468^{* * *} \\
(2.050)\end{array}$ \\
\hline Constant & $\begin{array}{c}-4.272^{* *} \\
(1.786) \\
\end{array}$ & $\begin{array}{c}-3.881 * * * \\
(0.977) \\
\end{array}$ & $\begin{array}{l}-4.213 * * * \\
(1.059)\end{array}$ & $\begin{array}{c}-4.258^{* * *} \\
(1.149) \\
\end{array}$ \\
\hline Observations & 9,843 & 9,843 & 9,843 & 9,843 \\
\hline Log likelihood & -18393 & -18408 & -19814 & -19831 \\
\hline
\end{tabular}

Regression errors clustered around researchers, robust standard errors in parentheses.

Sample restricted to NZ based researchers with a full proposal in the previous 5 years

Time \& panel dummies in count regressions, time dummies in zero inflated regressions 
Appendix Tables 5 and 6 run zero inflated negative binomial models with clustered errors on panel subsamples of researchers. These are the individual-researcher equivalents to the panel regressions in part III. The eight largest panels were chosen and to be included in a given regression, a researcher must have submitted a second stage proposal to the relevant panel in the preceding five years. Individuals who have submitted full proposals to two or more of these eight panels are included in more than one regression. As can be observed, the noise associated with small subsamples makes precise estimation difficult. For the publications regressions, researchers involved with the Biomedical Sciences (BMS), Cellular, Molecular and Physiological biology (CMP), Ecology, Evolution and Behaviour (EEB) and Social Sciences (SOC) panels are estimated to experience positive funding effects ranging from $\sim 6 \%$ to $\sim 9 \%$ per year for 5 years. Researchers involved in other panels experience statistically zero funding effects. For normalised citations, the regressions are noisier and only BMS has a statistically positive funding effect at $\sim 12 \%$.

\section{Summary and Conclusion}

All of the these estimation results are consistent with a modest but statistically robust boost in research output associated with receiving Marsden funding, although the statistical precision and exact size of the estimate depends on the empirical formulation. The effect on citations is consistently larger than the effect on publications, suggesting that funding leads both to more papers and papers that are more highly cited. ${ }^{9}$ It is important to emphasize that what is captured here is a general impact on the publication/citation success of the researchers. It seems likely that Marsden funding shifts researchers' focus to some extent towards the subject of the grant, so that the funding impact on research outputs directly related to the proposal would be greater than those estimated here, but our empirical framework does not allow us to measure that.

We also cannot determine the extent to which the increase comes from direct use of the Marsden money versus indirect impact of Marsden success on researcher opportunities and resources. Whether this is a weakness or strength of the findings depends on the question being asked. The Marsden fund is the premier basic science funding mechanism in New Zealand, and participants certainly believe that Marsden success is a general certification of quality that often translates into broader success. From the perspective of the Marsden Fund itself, it may make sense to attribute all of this success to Marsden. From the broader perspective of the social return to public science investment, the apparent benefit of Marsden funding may include

${ }^{9}$ If citations/paper is used explicitly as the success measure, the funding dummy has the expected coefficient but it is not statistically significant. 
double-counting of benefits associated with other public research funds, if part of the Marsden effect is greater success in receiving those other funds.

While our initial intention was to include panel rank in the analysis to control for selectivity bias, we find no evidence of selection based on likely research success in the second round Marsden process. We have tested many different versions of how that selection might operate, including trying both panel scores and raw referee scores, testing for an effect with or without conditioning on prior performance, testing for a variety of non-linearities in the selection effect, and testing for predictive power of panel rank comparing proposals with the same funding status. There really seems to be nothing there. It is possible that some other evaluation mechanism would do a better job, but there are several reasons to believe that distinguishing among these proposals ex ante is very hard:

- the inherent uncertainty of research success;

- the two-step Marsden process means the panels are attempting to distinguish among the merits of proposals in the upper tail of the population;

- the broad disciplinary coverage of the Marsden panels means that the panels are frequently comparing apples to oranges. ${ }^{10}$

Given the significant researcher and RSNZ time and resources that are devoted to second-round selection, this suggests a potentially large misallocation of resources.

Publications and citations are, of course, only proxies for research output. One could argue that the lack of a positive correlation between ex ante evaluations and performance by these metrics reflects a specific effort by the panels to identify research proposals with a particular kind of potential that is not captured by these metrics. We cannot rule out this possibility, but we find it hard to describe a plausible conception of the programme's goals that, if successful, would not produce research that would be expected to be highly cited.

The investigator-year analysis provides qualitatively similar results to those from the proposal-team quasi-experimental analysis. We do not yet understand why the estimated funding effect is smaller for the researcher-year model (3-5\% for publications and 5-8\% for citations) than for the project-team model (6-15\% for pubs and $22-26 \%$ for citations). These are, of course, not apples-to-apples comparisons, as the former is a change for each of the subsequent 5 years, while the latter is an average percentage increase over the entire remaining observation period. The simulation results in Figure 3 show that there is some additional benefit to funding that flows through the cumulative effect of performance on future performance. But this effect does not appear to be large enough to explain the difference. It is also true that the percentage

10 We speculate that this last factor likely explains the contrast between our results and those of $\mathrm{Li}$ and Agha (2015), who found that NIH peer review scores have significant explanatory power regarding subsequent performance, within the set of funded researchers. 
benefit for the team as a whole is not arithmetically equivalent to the average percentage benefit enjoyed by each member of the team. But it remains puzzling that difference is systematic and apparently large.

The two sets of results bracket those of Jacob and Lefgren (2011), who found an increase in publications of about $7 \%$. They suggested that this relatively small effect was likely do to the variety of funding options available to NIH researchers in the U.S. It is hard to say conclusively, but it appears that there are fewer alternatives to Marsden funding for fundamental science research in New Zealand. Further, the Jacob and Lefgren results are for Individual Researcher (R01) grants, while research teams are a prominent aspect of the Marsden proposals. It is likely that the true importance of the Marsden grant varies significantly across the members of the team, in ways that are not captured very well by the recorded FTE figures. If so, this means that the treatment effect is measured with considerable error in the individual-year model, which implicitly assumes that every New Zealand researcher on a Marsden grant is affected by the grant in the same way. For the project-team analysis, this problem is greatly mitigated. It is much more reasonable to think that across research teams, the benefit of grant receipt is roughly the same for different teams, particularly since there is relatively little variation in the budget sizes. This line of thought suggests that the individual-year estimate of the treatment effect is biased downward, and the project team estimates may be more reflective of the true treatment effect.

More generally, the analysis demonstrates the benefit of retaining and utilizing information on both successful and unsuccessful grant proposals. This basic strategy for identifying the treatment effect in the presence of potential selection bias is powerful in concept but very rarely applied in practice. 


\section{References}

Arora, Ashish, \& Gambardella, Alfonso. 2005. The impact of NSF support for basic research in economics. Annales d'Economie et de Statistique, 91-117.

Arora, Ashish, David, Paul A, \& Gambardella, Alfonso. 2000. Reputation and competence in publicly funded science: estimating the effects on research group productivity. Pages 141 176 of: The Economics and Econometrics of Innovation. Springer.

Benavente, Jose Miguel, Crespi, Gustavo, Figal Garone, Lucas, \& Maffioli, Alessandro. 2012. The impact of national research funds: A regression discontinuity approach to the Chilean FONDECYT. Research Policy, 41(8), 1461-1475.

Chabris, Christopher and Daniel Simons, 2010. The Invisible Gorilla: And Other Ways Our Intuitions Deceive Us, Random House

Chudnovsky, Daniel, Lopez, Andres, Rossi, Martin A, \& Ubfal, Diego. 2008. Money for Science? The Impact of Research Grants on Academic Output*. Fiscal Studies, 29(1), 75-87.

Fogelholm, Mikael, Saara Leppinen, Anssi Auvinen, Jani Raitanen, Anu Nuutinen, and Kalervo Väänänen. "Panel Discussion Does Not Improve Reliability of Peer Review for Medical Research Grant Proposals." Journal of Clinical Epidemiology 65, no. 1 (January 2012): 47-52. doi:10.1016/j.jclinepi.2011.05.001.

Gerritsen, Sander, \& Plug, Erik. 2013. Up or out? How individual research grants affect academic careers in the Netherlands. CPB Netherlands Bureau for Economic Policy Analysis.

Graves, Nicholas, Barnett, Adrian G, \& Clarke, Philip. 2011. Funding grant proposals for scientific research: retrospective analysis of scores by members of grant review panel. BMJ, 343 .

Horton, Nicholas, Kim, Eugenia \& Saitz, Richard. 2007. A cautionary note regarding count models of alcohol consumption in randomised controlled trials. BMC Medical Research Methodology, 7(9), 1-9.

Imbens, Guido, \& Kalyanaraman, Karthik. 2011. Optimal Bandwidth Choice for the Regression Discontinuity Estimator. The Review of Economic Studies, rdr043.

Imbens, Guido W, \& Lemieux, Thomas. 2008. Regression discontinuity designs: A guide to practice., Journal of Econometrics, 142(2), 615-635.

Jacob, Brian A, \& Lefgren, Lars. 2004. Remedial education and student achievement: A regression-discontinuity analysis. Review of Economics and Statistics, 86(1), 226-244.

Jacob, Brian A, \& Lefgren, Lars. 2011. The impact of research grant funding on scientific productivity. Journal of Public Economics, 95(9), 1168-1177.

Jacob, Robin Tepper, Zhu, Pei, Somers, Marie-Andree, \& Bloom, Howard S. 2012. A Practical Guide to Regression Discontinuity. MDRC.

Jaffe, Adam B. 2002. Building programme evaluation into the design of public research-support programmes. Oxford Review of Economic Policy, 18(1), 22-34.

Kahneman, Daniel, 2011. Thinking Fast and Slow, Farrar, Straus and Giroux 
Knox, Andrea. 2004. The Impact of Marsden-funded Research: a bibliometric assessment of Marsdenfunded publications, 1997-2001. The Royal Society of New Zealand.

Lee, Hyunshik, \& Munk, Tom. 2008. Using Regression Discontinuity Design for Program Evaluation.

Li, Danielle, and Leila Agha. 2015. "Big Names or Big Ideas: Do Peer-Review Panels Select the Best Science Proposals?” Science 348, no. 6233 (April 24, 2015): 434-38. doi:10.1126/science.aaa0185

Li, Danielle and Leila Agha. "Big Names or Big Ideas: Do Peer-Review Panels Select the Best Science Proposals?”-Supplementary Materials (mimeo, 2015)

McCrary, Justin. 2008. Manipulation of the running variable in the regression discontinuity design: A density test. Journal of Econometrics, 142(2), 698-714.

Rubin, Donald B. 1977. Assignment to Treatment Group on the Basis of a Covariate. Journal of Educational and Behavioral Statistics, 2(1), 1-26.

Stephan, Paula E. 1996. The economics of science. Journal of Economic literature, 1199-1235.

Thistlethwaite, Donald L, \& Campbell, Donald T. 1960. Regression-discontinuity analysis: An alternative to the ex post facto experiment. Journal of Educational Psychology, 51(6), 309

Wang, D., Song, C. \& Barabási, A-L. Science 342, 127-132 (2013). 


\section{Appendix}

\section{Information on panels}

\begin{tabular}{|c|c|c|c|}
\hline & \multicolumn{2}{|r|}{ Categories } & Research areas \\
\hline \multirow{12}{*}{ Single panels } & \multicolumn{2}{|r|}{ MIS } & Mathematical and Information Sciences \\
\hline & \multicolumn{2}{|r|}{ ESA } & Earth Sciences and Astronomy \\
\hline & \multicolumn{2}{|r|}{ PSE } & Physical Sciences and Engineering \\
\hline & \multicolumn{2}{|r|}{ EIS } & Engineering and Interdisciplinary Sciences \\
\hline & \multicolumn{2}{|r|}{ PCB } & Physics, Chemistry and Biochemistry \\
\hline & \multicolumn{2}{|r|}{$\mathrm{B} \& \mathrm{~B}$} & Biochemical and biomedical sciences \\
\hline & \multicolumn{2}{|r|}{ CMP } & Cellular, Molecular and Physiological biology \\
\hline & \multicolumn{2}{|r|}{ EEB } & Ecology, Evolution and Behaviour \\
\hline & \multicolumn{2}{|r|}{ BMS } & Biomedical sciences \\
\hline & \multicolumn{2}{|r|}{ SOC } & Social Sciences \\
\hline & \multicolumn{2}{|r|}{ HUM } & Humanities \\
\hline & \multicolumn{2}{|r|}{ EHB } & Economics and Human Behaviour \\
\hline \multirow{3}{*}{ Broad areas } & LIF & $\begin{array}{l}\mathrm{B} \& \mathrm{~B}+\mathrm{CMP}+\mathrm{EEB}+\mathrm{B} \\
\mathrm{MS}\end{array}$ & Life sciences \\
\hline & HSC & SOC+HUM+EHB & Humanities and social sciences \\
\hline & PSM & $\begin{array}{l}\text { MIS+ESA+PSE+EIS } \\
+\mathrm{PCB}\end{array}$ & Physical sciences and mathematics \\
\hline \multirow{3}{*}{$\begin{array}{l}\text { Across two } \\
\text { broad areas }\end{array}$} & LPM & $\mathrm{LIF}+\mathrm{PSM}$ & $\begin{array}{l}\text { Life sciences, physical sciences and } \\
\text { mathematics }\end{array}$ \\
\hline & LSH & $\mathrm{LIF}+\mathrm{HSC}$ & Life sciences, humanities and social sciences \\
\hline & SPM & $\mathrm{HSC}+\mathrm{PSM}$ & $\begin{array}{l}\text { Social sciences, humanities, physical sciences } \\
\text { and mathematics }\end{array}$ \\
\hline All areas & ALL & $\mathrm{LIF}+\mathrm{HSC}+\mathrm{PSM}$ & Broadly interdisciplinary \\
\hline
\end{tabular}

For the proposal-team dataset, dichotomous variables for the nine panels in operation from 2003-2008 are included (MIS, ESA, PSE, CMP, EEB, BMS, SOC, HUM, EHB).

For the investigator-panel dataset, nineteen dichotomous variables for panels are included. Twelve are for specific panels in operation during the timeframe (MIS, ESA, PSE, EIS, PCB, B\&B, CMP, EEB, BMS, SOC, HUM, EHB). The remaining nine are grouped classifications relevant when a researcher was involved with more than one panel in a given year - either by submitting two or more proposals to separate panels and/or one proposal to two or more panels. The groupings are displayed in the table above. 
Appendix Table 1

Year and Panel statistics from proposal-team dataset. 2003-2008.

\begin{tabular}{|c|c|c|}
\hline & $\begin{array}{l}\text { Number of } \\
\text { Observations }\end{array}$ & $\begin{array}{c}\text { Dummy coefficient from Column } \\
4 \text {, Table } 3\end{array}$ \\
\hline 2003 & 168 & $\begin{array}{c}\text { n.a. } \\
\text { (.) }\end{array}$ \\
\hline 2004 & 195 & $\begin{array}{l}0.250^{* * *} \\
(0.0752)\end{array}$ \\
\hline 2005 & 207 & $\begin{array}{c}0.0891 \\
(0.0737)\end{array}$ \\
\hline 2006 & 241 & $\begin{array}{c}0.0385 \\
(0.0748)\end{array}$ \\
\hline 2007 & 233 & $\begin{array}{c}0.0174 \\
(0.0746)\end{array}$ \\
\hline 2008 & 219 & $\begin{array}{c}0.0418 \\
(0.0777)\end{array}$ \\
\hline BMS & 145 & $\begin{array}{c}\text { n.a. } \\
(.)\end{array}$ \\
\hline CMP & 167 & $\begin{array}{c}-0.257 * * * \\
(0.0768)\end{array}$ \\
\hline EEB & 188 & $\begin{array}{c}0.0248 \\
(0.0746)\end{array}$ \\
\hline ЕНB & 61 & $\begin{array}{c}-0.271 * * * \\
(0.105)\end{array}$ \\
\hline ESA & 122 & $\begin{array}{l}-0.0697 \\
(0.0825)\end{array}$ \\
\hline HUM & 96 & $\begin{array}{c}-1.035^{* * *} \\
(0.134)\end{array}$ \\
\hline MIS & 118 & $\begin{array}{c}-0.315^{* * *} \\
(0.0853)\end{array}$ \\
\hline PSE & 164 & $\begin{array}{l}-0.0897 \\
(0.0771)\end{array}$ \\
\hline SOC & 202 & $\begin{array}{c}-0.516^{* * *} \\
(0.0791)\end{array}$ \\
\hline
\end{tabular}


Appendix Table 2

Year and Panel statistics from researcher-panel dataset. 2004-2012.

\begin{tabular}{|c|c|c|}
\hline & Number of Observations & Dummy coefficient from Column 8 , Table 6 \\
\hline 2004 & 660 & $\begin{array}{c}\text { n.a. } \\
(.)\end{array}$ \\
\hline 2005 & 876 & $\begin{array}{c}0.0587 \\
(0.0993)\end{array}$ \\
\hline 2006 & 1030 & $\begin{array}{l}0.0666 \\
(0.103)\end{array}$ \\
\hline 2007 & 1217 & $\begin{array}{l}0.0420 \\
(0.106)\end{array}$ \\
\hline 2008 & 1382 & $\begin{array}{l}0.0923 \\
(0.110)\end{array}$ \\
\hline 2009 & 1411 & $\begin{array}{c}0.00930 \\
(0.102)\end{array}$ \\
\hline 2010 & 1246 & $\begin{array}{c}0.109 \\
(0.108)\end{array}$ \\
\hline 2011 & 1101 & $\begin{array}{c}0.169 \\
(0.112)\end{array}$ \\
\hline 2012 & 939 & $\begin{array}{c}0.445^{* * *} \\
(0.118)\end{array}$ \\
\hline$\overline{\text { ALL }}$ & 12 & $\begin{array}{c}\text { n.a. } \\
(.)\end{array}$ \\
\hline B\&B & 9 & $\begin{array}{c}0.192 \\
(0.460)\end{array}$ \\
\hline BMS & 1022 & $\begin{array}{c}0.199 \\
(0.352)\end{array}$ \\
\hline CMP & 893 & $\begin{array}{c}0.176 \\
(0.351)\end{array}$ \\
\hline EEB & 1201 & $\begin{array}{c}0.278 \\
(0.350)\end{array}$ \\
\hline EHB & 507 & $\begin{array}{l}0.0782 \\
(0.356)\end{array}$ \\
\hline EIS & 97 & $\begin{array}{c}0.419 \\
(0.368)\end{array}$ \\
\hline ESA & 1057 & $\begin{array}{l}0.339 \\
(0.356)\end{array}$ \\
\hline HSC & 306 & $\begin{array}{c}0.170 \\
(0.380)\end{array}$ \\
\hline HUM & 521 & $\begin{array}{c}0.425 \\
(0.402)\end{array}$ \\
\hline LIF & 397 & $\begin{array}{c}0.352 \\
(0.356)\end{array}$ \\
\hline LPM & 487 & $\begin{array}{c}0.323 \\
(0.355)\end{array}$ \\
\hline LSH & 125 & $\begin{array}{l}0.719^{*} \\
(0.384)\end{array}$ \\
\hline MIS & 610 & $\begin{array}{c}0.440 \\
(0.357)\end{array}$ \\
\hline РCB & 192 & $\begin{array}{l}0.136 \\
(0.363)\end{array}$ \\
\hline PSE & 824 & $\begin{array}{c}0.352 \\
(0.352)\end{array}$ \\
\hline PSM & 98 & $\begin{array}{c}0.138 \\
(0.379)\end{array}$ \\
\hline SOC & 1428 & $\begin{array}{l}0.326 \\
(0.356)\end{array}$ \\
\hline SPM & 76 & $\begin{array}{c}0.354 \\
(0.378)\end{array}$ \\
\hline
\end{tabular}


Appendix Table 3: Negative Binomial Regressions by panel (discipline) on proposal-team data - Publications

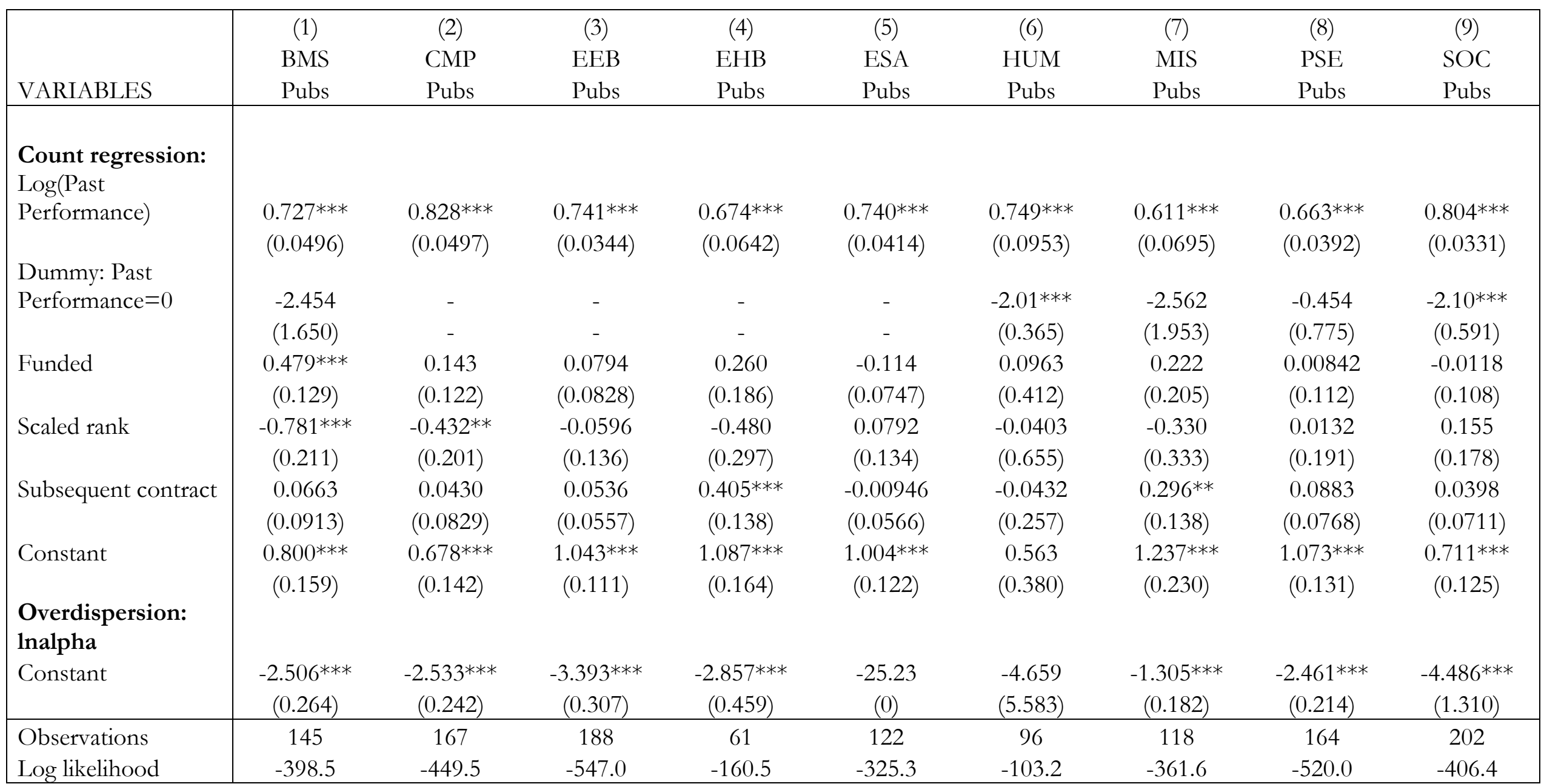

Time and panel dummies included in all regressions

EHB began in 2006. Dummies for 2007/2008 only included

No past performance dummy omitted from CMP EEB EHB and ESA as past publications values all positive

Standard errors in parentheses

*** $\mathrm{p}<0.01, * * \mathrm{p}<0.05, * \mathrm{p}<0.1$ 
Appendix Table 4: Negative Binomial Regressions by panel (discipline) on proposal-team data - Citations

\begin{tabular}{|c|c|c|c|c|c|c|c|c|c|}
\hline VARIABLES & $\begin{array}{l}(1) \\
\text { BMS } \\
\text { Cites }\end{array}$ & $\begin{array}{l}(2) \\
\text { CMP } \\
\text { Cites }\end{array}$ & $\begin{array}{l}(3) \\
\text { EEB } \\
\text { Cites }\end{array}$ & $\begin{array}{l}(4) \\
\text { EHB } \\
\text { Cites }\end{array}$ & $\begin{array}{l}(5) \\
\text { ESA } \\
\text { Cites }\end{array}$ & $\begin{array}{c}(6) \\
\text { HUM } \\
\text { Cites }\end{array}$ & $\begin{array}{l}(7) \\
\text { MIS } \\
\text { Cites }\end{array}$ & $\begin{array}{l}(8) \\
\text { PSE } \\
\text { Cites }\end{array}$ & $\begin{array}{l}(9) \\
\text { SOC } \\
\text { Cites }\end{array}$ \\
\hline $\begin{array}{l}\text { Count regression: } \\
\text { Log(Past } \\
\text { Performance })\end{array}$ & $\begin{array}{l}0.420 * * * \\
(0.0663)\end{array}$ & $\begin{array}{l}0.689 * * * \\
(0.0453)\end{array}$ & $\begin{array}{l}0.628^{* * *} \\
(0.0336)\end{array}$ & $\begin{array}{l}0.539 * * * \\
(0.0424)\end{array}$ & $\begin{array}{l}0.669 * * * \\
(0.0514)\end{array}$ & $\begin{array}{l}0.665^{* * *} \\
(0.0725)\end{array}$ & $\begin{array}{l}0.679 * * * \\
(0.0468)\end{array}$ & $\begin{array}{l}0.763^{* * *} \\
(0.0459)\end{array}$ & $\begin{array}{l}0.766^{* * *} \\
(0.0360)\end{array}$ \\
\hline $\begin{array}{l}\text { Dummy: Past } \\
\text { Performance }=0\end{array}$ & $\begin{array}{c}-2.377 * * \\
(0.946)\end{array}$ & $\begin{array}{l}- \\
-\end{array}$ & $\begin{array}{l}- \\
-\end{array}$ & $\begin{array}{l}- \\
-\end{array}$ & $\begin{array}{l}- \\
-\end{array}$ & $\begin{array}{c}-1.890 * * * \\
(0.416)\end{array}$ & $\begin{array}{l}-3.046 \\
(2.751)\end{array}$ & $\begin{array}{l}1.752^{* *} \\
(0.734)\end{array}$ & $\begin{array}{c}-1.706^{* * *} \\
(0.622)\end{array}$ \\
\hline Funded & $\begin{array}{c}0.668 * * * \\
(0.229)\end{array}$ & $\begin{array}{l}0.199 \\
(0.158)\end{array}$ & $\begin{array}{l}0.0956 \\
(0.133)\end{array}$ & $\begin{array}{l}-0.0984 \\
(0.236)\end{array}$ & $\begin{array}{c}0.127 \\
(0.142)\end{array}$ & $\begin{array}{l}-0.531 \\
(0.491)\end{array}$ & $\begin{array}{l}0.455^{* *} \\
(0.226)\end{array}$ & $\begin{array}{c}0.241 \\
(0.183)\end{array}$ & $\begin{array}{c}0.522^{* * *} \\
(0.181)\end{array}$ \\
\hline Scaled rank & $\begin{array}{c}-0.951 * * \\
(0.382)\end{array}$ & $\begin{array}{l}-0.493^{*} \\
(0.257)\end{array}$ & $\begin{array}{l}-0.0783 \\
(0.222)\end{array}$ & $\begin{array}{c}0.175 \\
(0.381)\end{array}$ & $\begin{array}{c}0.309 \\
(0.243)\end{array}$ & $\begin{array}{c}1.162 \\
(0.760)\end{array}$ & $\begin{array}{l}-0.577 \\
(0.380)\end{array}$ & $\begin{array}{l}-0.581 * \\
(0.303)\end{array}$ & $\begin{array}{l}-0.411 \\
(0.294)\end{array}$ \\
\hline Subsequent contract & $\begin{array}{c}0.430 * * * \\
(0.160)\end{array}$ & $\begin{array}{c}0.231 * * \\
(0.108)\end{array}$ & $\begin{array}{c}0.165^{*} \\
(0.0935)\end{array}$ & $\begin{array}{c}0.280 \\
(0.185)\end{array}$ & $\begin{array}{c}0.106 \\
(0.104)\end{array}$ & $\begin{array}{l}-0.0692 \\
(0.319)\end{array}$ & $\begin{array}{c}0.447 * * * \\
(0.161)\end{array}$ & $\begin{array}{c}0.141 \\
(0.119)\end{array}$ & $\begin{array}{c}0.440 * * * \\
(0.124)\end{array}$ \\
\hline $\begin{array}{l}\text { Constant } \\
\text { Overdispersion: } \\
\text { lnalpha }\end{array}$ & $\begin{array}{c}2.626^{* * *} \\
(0.473)\end{array}$ & $\begin{array}{l}1.263^{* * *} \\
(0.277)\end{array}$ & $\begin{array}{l}1.811 * * * \\
(0.231)\end{array}$ & $\begin{array}{c}1.666^{* * *} \\
(0.245)\end{array}$ & $\begin{array}{c}1.415^{* * *} \\
(0.309)\end{array}$ & $\begin{array}{l}-0.0230 \\
(0.538)\end{array}$ & $\begin{array}{c}1.140 * * * \\
(0.304)\end{array}$ & $\begin{array}{l}0.928^{* * *} \\
(0.288)\end{array}$ & $\begin{array}{c}0.543^{* * *} \\
(0.203)\end{array}$ \\
\hline Constant & $\begin{array}{c}-0.481 * * * \\
(0.110) \\
\end{array}$ & $\begin{array}{c}-1.173^{* * *} \\
(0.108) \\
\end{array}$ & $\begin{array}{c}-1.281 * * * \\
(0.103) \\
\end{array}$ & $\begin{array}{c}-1.397 * * * \\
(0.189) \\
\end{array}$ & $\begin{array}{c}-1.540^{* * *} \\
(0.133) \\
\end{array}$ & $\begin{array}{c}-0.609 * * \\
(0.275) \\
\end{array}$ & $\begin{array}{c}-0.718^{* * *} \\
(0.133) \\
\end{array}$ & $\begin{array}{c}-0.953 * * * \\
(0.108) \\
\end{array}$ & $\begin{array}{c}-0.755^{* * *} \\
(0.114) \\
\end{array}$ \\
\hline $\begin{array}{l}\text { Observations } \\
\text { Log likelihood }\end{array}$ & $\begin{array}{c}145 \\
-885.3\end{array}$ & $\begin{array}{c}167 \\
-951.5\end{array}$ & $\begin{array}{c}188 \\
-1135\end{array}$ & $\begin{array}{c}61 \\
-307.1\end{array}$ & $\begin{array}{c}122 \\
-705.0\end{array}$ & $\begin{array}{c}96 \\
-165.2\end{array}$ & $\begin{array}{c}118 \\
-580.9\end{array}$ & $\begin{array}{c}164 \\
-959.4\end{array}$ & $\begin{array}{c}202 \\
-830.8\end{array}$ \\
\hline
\end{tabular}

Time and panel dummies included in all regressions

EHB began in 2006. Dummies for 2007/2008 only included

No past performance dummy omitted from CMP EEB EHB and ESA as past citations values all positive

Standard errors in parentheses

*** $\mathrm{p}<0.01, * * \mathrm{p}<0.05, * \mathrm{p}<0.1$ 
Appendix Table 5: Zero inflated negative binomial regressions by panel (discipline) on investigator-panel data: publications

\begin{tabular}{|c|c|c|c|c|c|c|c|c|}
\hline VARIABLES & $\begin{array}{c}(1) \\
\text { BMS } \\
\text { Pubs }\end{array}$ & $\begin{array}{c}(2) \\
\text { CMP } \\
\text { Pubs }\end{array}$ & $\begin{array}{c}(3) \\
\text { EEB } \\
\text { Pubs }\end{array}$ & $\begin{array}{c}(4) \\
\text { ESA } \\
\text { Pubs }\end{array}$ & $\begin{array}{c}(5) \\
\text { HUM } \\
\text { Pubs }\end{array}$ & $\begin{array}{c}(6) \\
\text { MIS } \\
\text { Pubs }\end{array}$ & $\begin{array}{c}(7) \\
\text { PSE } \\
\text { Pubs }\end{array}$ & $\begin{array}{c}(8) \\
\text { SOC } \\
\text { Pubs }\end{array}$ \\
\hline \multicolumn{9}{|l|}{ Count regression: } \\
\hline Log(Average Performance over past 5 years) & $\begin{array}{c}0.822^{* * *} \\
(0.0256)\end{array}$ & $\begin{array}{c}0.749 * * * \\
(0.0288)\end{array}$ & $\begin{array}{c}0.708 * * * \\
(0.0315)\end{array}$ & $\begin{array}{c}0.762^{* * *} \\
(0.0330)\end{array}$ & $\begin{array}{c}0.704 * * * \\
(0.0680)\end{array}$ & $\begin{array}{c}0.865^{* * *} \\
(0.0432)\end{array}$ & $\begin{array}{c}0.787 * * * \\
(0.0313)\end{array}$ & $\begin{array}{c}0.828^{* * *} \\
(0.0276)\end{array}$ \\
\hline Number of contracts in past 5 years & $\begin{array}{c}0.0642^{* *} \\
(0.0298)\end{array}$ & $\begin{array}{c}0.0755^{* * *} \\
(0.0256)\end{array}$ & $\begin{array}{c}0.0582^{* *} \\
(0.0234)\end{array}$ & $\begin{array}{c}0.0266 \\
(0.0277)\end{array}$ & $\begin{array}{c}0.201 \\
(0.149)\end{array}$ & $\begin{array}{l}-0.0308 \\
(0.0403)\end{array}$ & $\begin{array}{l}-0.0116 \\
(0.0359)\end{array}$ & $\begin{array}{c}0.0882^{* *} \\
(0.0360)\end{array}$ \\
\hline Max lagged scaled rank & $\begin{array}{c}-0.139 \\
(0.0975)\end{array}$ & $\begin{array}{l}-0.160^{*} \\
(0.0878)\end{array}$ & $\begin{array}{c}-0.000331 \\
(0.0791)\end{array}$ & $\begin{array}{c}-0.0669 \\
(0.104)\end{array}$ & $\begin{array}{c}0.137 \\
(0.320)\end{array}$ & $\begin{array}{c}-0.00887 \\
(0.138)\end{array}$ & $\begin{array}{c}0.0502 \\
(0.0993)\end{array}$ & $\begin{array}{l}0.0235 \\
(0.107)\end{array}$ \\
\hline Constant & $\begin{array}{l}0.199 * * \\
(0.0813)\end{array}$ & $\begin{array}{c}0.241 * * * \\
(0.0674)\end{array}$ & $\begin{array}{c}0.470 * * * \\
(0.0674)\end{array}$ & $\begin{array}{c}0.504 * * * \\
(0.0941)\end{array}$ & $\begin{array}{c}0.137 \\
(0.303)\end{array}$ & $\begin{array}{c}0.555^{* * *} \\
(0.106)\end{array}$ & $\begin{array}{c}0.468 * * * \\
(0.0715)\end{array}$ & $\begin{array}{l}0.186^{*} \\
(0.103)\end{array}$ \\
\hline \multicolumn{9}{|l|}{ Overdispersion: lnalpha } \\
\hline Constant & $\begin{array}{c}-1.896^{* * *} \\
(0.120)\end{array}$ & $\begin{array}{c}-1.939 * * * \\
(0.159)\end{array}$ & $\begin{array}{c}-1.818^{* * *} \\
(0.115)\end{array}$ & $\begin{array}{c}-1.673^{* * *} \\
(0.128)\end{array}$ & $\begin{array}{c}-0.911 * * * \\
(0.231)\end{array}$ & $\begin{array}{c}-1.569 * * * \\
(0.135)\end{array}$ & $\begin{array}{c}-1.807 * * * \\
(0.115)\end{array}$ & $\begin{array}{c}-1.864^{* * *} \\
(0.191)\end{array}$ \\
\hline \multicolumn{9}{|l|}{ Zero inflation regression } \\
\hline Log(Average Performance over past 5 years) & $\begin{array}{c}-1.856^{* * *} \\
(0.703)\end{array}$ & $\begin{array}{l}-0.158 \\
(0.245)\end{array}$ & $\begin{array}{c}-0.580 * * \\
(0.262)\end{array}$ & $\begin{array}{c}0.207 \\
(0.804)\end{array}$ & $\begin{array}{l}0.0545 \\
(0.397)\end{array}$ & $\begin{array}{c}-43.43^{* * *} \\
(1.345)\end{array}$ & $\begin{array}{c}-64.04 * * * \\
(3.500)\end{array}$ & $\begin{array}{l}-0.181 \\
(0.469)\end{array}$ \\
\hline Dummy: Performance in past 5 years $=0$ & $\begin{array}{c}34.27 * * * \\
(1.064)\end{array}$ & $\begin{array}{c}-12.04 * * * \\
(2.078)\end{array}$ & $\begin{array}{c}0.852 \\
(11.21)\end{array}$ & $\begin{array}{c}38.70^{* * *} \\
(1.879)\end{array}$ & $\begin{array}{c}1.794 \\
(2.479)\end{array}$ & $\begin{array}{c}98.55^{* * *} \\
(5.737)\end{array}$ & $\begin{array}{c}136.0^{* * *} \\
(7.081)\end{array}$ & $\begin{array}{c}5.956^{* * *} \\
(1.534)\end{array}$ \\
\hline Constant & $\begin{array}{c}-20.01^{* * *} \\
(1.180) \\
\end{array}$ & $\begin{array}{c}-16.99 * * * \\
(0.571) \\
\end{array}$ & $\begin{array}{c}-18.46^{* * *} \\
(1.385) \\
\end{array}$ & $\begin{array}{c}-20.16^{* * *} \\
(1.715) \\
\end{array}$ & $\begin{array}{l}-1.268 \\
(1.204) \\
\end{array}$ & $\begin{array}{c}-54.94 * * * \\
(1.867) \\
\end{array}$ & $\begin{array}{c}-75.44 * * * \\
(3.290) \\
\end{array}$ & $\begin{array}{c}-4.179 * * * \\
(1.612)\end{array}$ \\
\hline Observations & 1,534 & 1,632 & 1,861 & 1,404 & 699 & 853 & 1,426 & 2,170 \\
\hline Log likelihood & -3173 & -3191 & -3952 & -2823 & -653.3 & -1847 & -3179 & -3073 \\
\hline
\end{tabular}

Regression errors clustered around researchers, robust standard errors in parentheses.

Sample restricted to NZ based researchers with a full proposal submitted to the relevant panel in the previous 5 years

Time \& panel dummies in count regressions, time dummies in zero inflated regressions 
Appendix Table 6: Zero inflated negative binomial regressions by panel (discipline) on investigator-panel data: citations

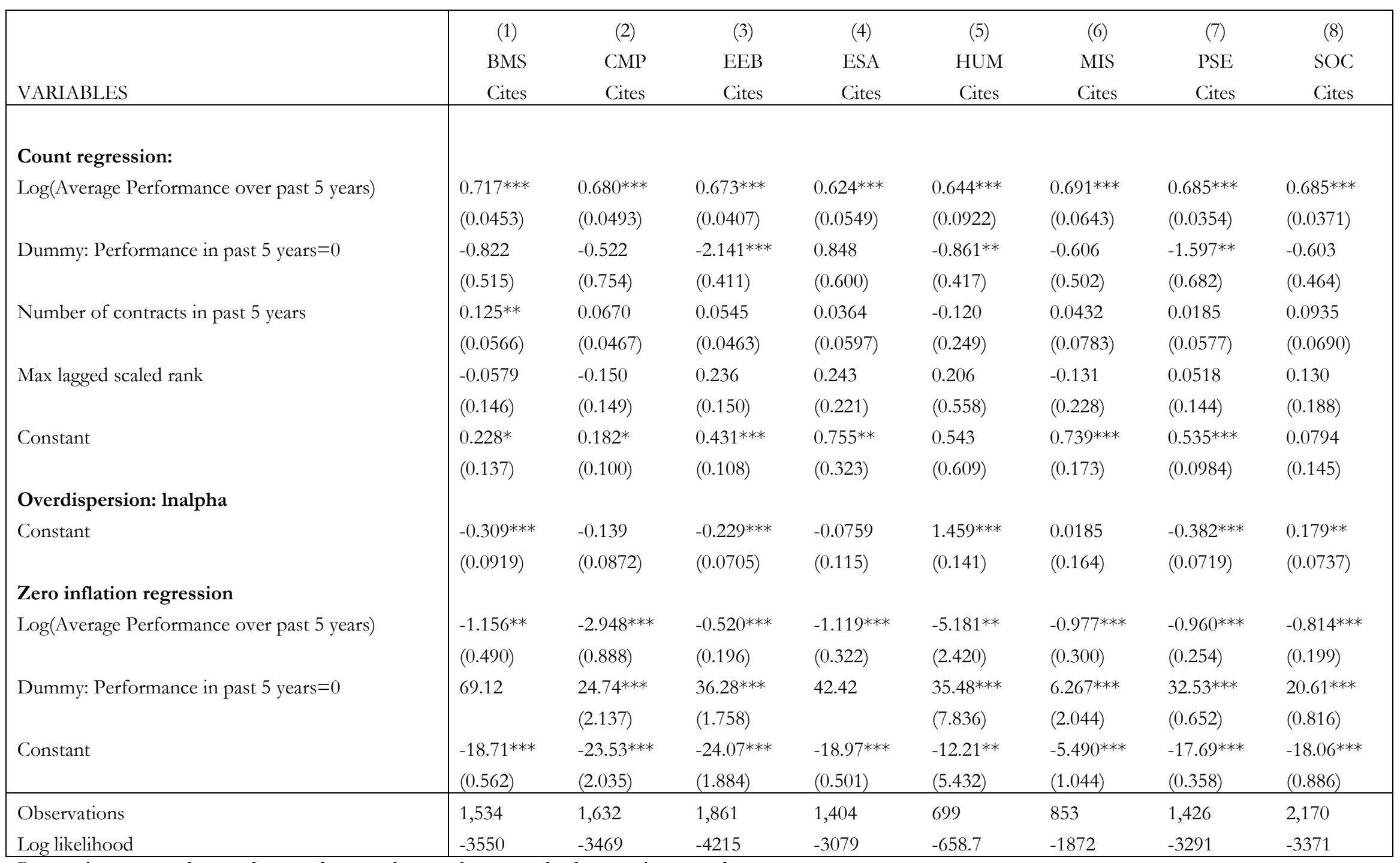

Regression errors clustered around researchers, robust standard errors in parentheses.

Sample restricted to NZ based researchers with a full proposal submitted to the relevant panel in the previous 5 years

Time \& panel dummies in count regressions, time dummies in zero inflated regressions 